\title{
Structure and zonation of demersal fish assemblages off the Azores Archipelago (mid-Atlantic)
}

\author{
Gui M. Menezes ${ }^{1, *}$, Michael F. Sigler ${ }^{2}$, Helder M. Silva ${ }^{1}$, Mario R. Pinho ${ }^{1}$ \\ ${ }^{1}$ Departamento de Oceanografia e Pescas, Universidade dos Açores, Cais de Santa Cruz, 9901-862 Horta, Portugal \\ ${ }^{2}$ US National Marine Fisheries Service, Alaska Fisheries Science Center, Auke Bay Laboratory, \\ 11305 Glacier Highway, Juneau, Alaska 99801, USA
}

\begin{abstract}
The assemblages of the demersal fish fauna of the Azores Archipelago are described from longline surveys that extended from the coastline to $1200 \mathrm{~m}$ water depth. A total of 104 fish species from 47 different families were caught, and despite the changes of biogeographic affinities with depth, most species caught are of subtropical origin (mainly from the Eastern Atlantic/Mediterranean areas) or have a broad geographic distribution. Four large-scale fish assemblages following a depthaligned structure were found: a shallow-shelf/shelf-break assemblage at depths $<200 \mathrm{~m}$, an upperslope assemblage at 200-600 m, a mid-slope assemblage at 600-800 m and a deep mid-slope assemblage at 800-1200 m. Within the main shallow assemblage, 4 small-scale fish assemblages were found: an inner-shelf-island assemblage, an outer-shelf-island assemblage, a seamount/islandshelf/shelf-break assemblage and a transitional shelf/break assemblage. The bathymetric delineation of the mid-slope assemblages coincides with the known distributions of the North Atlantic Central Water (NACW), Mediterranean Water (MW) and the upper influence of the intermediate waters in the region: the northern sub-polar waters (Subarctic Intermediate Water [SAIW], the Labrador Sea Water [LSW]) and the Antarctic Intermediate Water (AAIW). The delineation of the shallow small-scale fish assemblages appears to be determined by small-scale environmental factors (e.g. bottom characteristics, seamounts or island areas).
\end{abstract}

KEY WORDS: Azores Archipelago · Demersal fish assemblages · Islands · Seamounts · Fish distribution $\cdot$ Zonation $\cdot$ Water masses

\section{INTRODUCTION}

The ichthyofauna of the Azores islands has been studied since the end of the nineteenth century (Santos et al. 1995), and more than 460 marine fish species have been listed for the area (Santos et al. 1997). During the 1970s and 1980, fishing surveys were conducted by the former USSR (Vinnichenko 2002), Norway (Dias et al. 1976), and Portugal (Dias \& Cascalho 1991). In 1995, the Department of Oceanography and Fisheries (of the University of the Azores - DOP/UAç) began regular longline surveys (Menezes 2003), providing data for new descriptions of the structure and spatial distribution of demersal and deep-water fish assemblages in the Azores. In recent years, shelf fish assemblages also have been studied for several coastal habitats in the Azores (Azevedo 1997, Afonso 2001).

Description, structuring factors and persistence of demersal fish assemblages have been documented for several continental-shelf and -slope habitats (e.g. Colvocoresses \& Musick 1984, Overholtz \& Tyler 1985, Mahon \& Smith 1989, Bianchi 1992a,b,c, Gomes et al. 1992, 1995, 2001, McKenna 1993, Rogers et al. 1998, Gaertner 2000, Williams et al. 2001). Knowledge of the deep-demersal fish fauna in the Atlantic also has improved considerably in recent years (Mauchline \& Gordon 1985, Haedrich \& Merrett 1988, Merrett et al. 1991, Stefanescu et al. 1993, Gordon et al. 1996, Haedrich 1997, Merrett \& Haedrich 1997, Bergstad et al. 1999, D'Onghia et al. 2004). 
Benthic and benthopelagic fish communities typically are studied using bottom trawls. On the MidAtlantic Ridge (MAR), commercial trawling has been conducted, but only a few exploratory fishing surveys have used trawls (Hareide \& Garnes 2001, Vinnichenko, 2002). Recently, exploratory fishing targeting orange roughy Hoplostethus atlanticus took place within the Azores EEZ below $800 \mathrm{~m}$ depth, and more than 20 new fish species were recorded for the area (Melo \& Menezes 2002). The use of trawls in certain areas, such as the Atlantic islands, is difficult due to the steep, rocky and irregular bottom. Because of this, longlines have been used in most studies of the demersal and deep-water fish species assemblages in these archipelagos (Uiblein et al. 1996, Menezes 2003).

In this study, we characterize the structure and spatial distribution of the shelf and slope demersal fish fauna of the Azores islands and identify the main fish assemblages from a few meters to $1200 \mathrm{~m}$ water depth. To our knowledge, this is the first time that longline gear has been used to study the ecological features of the demersal ichthyofauna of the Azores over such a wide depth range. The objectives of this work were to (1) characterize the species composition and general structure of the catches, (2) determine major demersal fish assemblages of the Azores waters, as well as describe their general composition, spatial distribution, and characteristic species, and (3) examine and identify major fish-assemblage boundaries, elucidating, whenever possible, their environmental determinants.

\section{STUDY AREA}

The archipelago of the Azores (36 to $40^{\circ} \mathrm{N}, 24$ to $32^{\circ} \mathrm{W}$ ) is the most isolated and extensive island group in the northeastern Atlantic (Fig. 1). It is composed of 9 volcanic islands distributed in 3 groups along a tectonic zone extending about $600 \mathrm{~km}$ WNW-ESE and several small islets, with a coastline that totals about $790 \mathrm{~km}$. As a volcanic archipelago of recent origin, the Azores islands are characterized by very narrow shelves and steep slopes. The seafloor around the Azores is very irregular and rocky, with numerous submarine elevations of very different size, shape, depth and degrees of isolation. The size of the Azores EEZ is about $1000000 \mathrm{~km}^{2}$, with an average depth of about $3000 \mathrm{~m}$, but the exploitable fish habitat is relatively small, with the depths less than $600 \mathrm{~m}$ covering only about $1 \%$ of the entire EEZ (7000 km²; Menezes 2003). During winter a deep mixed layer is present around $150 \mathrm{~m}$, and in summer a seasonal thermocline develops around 40 to $100 \mathrm{~m}$. Average sea surface temperature varies between 15 and $20^{\circ} \mathrm{C}$ during winter and between 20 and $25^{\circ} \mathrm{C}$ during summer (Santos et al. 1995).

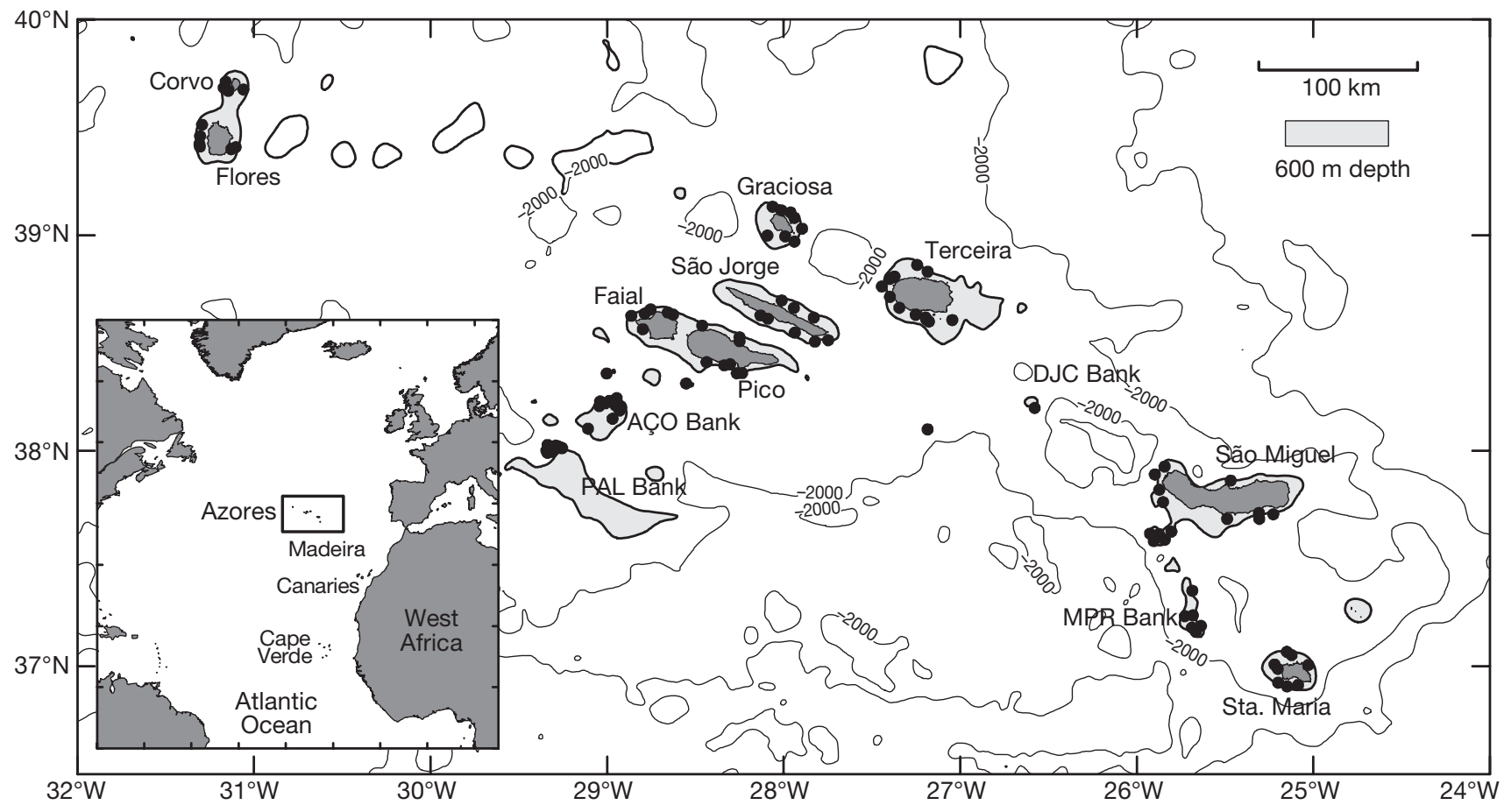

Fig. 1. The Azores archipelago. Location of fishing stations sampled during bottom longline surveys covered by the RV 'Arquipélago' in 1995, 1996, 1997, 1999, and 2000. Stations are indicated with circles. Abbeviations for the 4 banks covered during the cruises are as follows: PAL - Princesa Alice; AÇO - Açores; DJC - Dom João de Castro; MPR - Mar da Prata 
Currents. The Azores region is located at the northern edge of the North Atlantic Subtropical Gyre (SG), characterized by a high horizontal temperature gradient, with the oceanographic conditions being strongly influenced by the Gulf Stream western current, which transports warm water of equatorial and tropical origin into colder northern water. The current system that surrounds the Azores is complex (Alves \& Verdière 1999, Johnson \& Stevens 2000, Bashmachnikov et al. 2004). The system is largely dominated in the south by the warm Azores Front/Current (AFC or AzC) system, that crosses the MAR at 34 to $36^{\circ} \mathrm{N}$, and in the north by the cold southern branch of the North Atlantic Current (NAC; Alves \& Verdière 1999, Bashmachnikov et al. 2004). One additional flow lies between the NAC and the $\mathrm{AzC}$ and is found between 39 to $42^{\circ} \mathrm{N}$ (Bashmachnikov et al. 2004). In addition, mesoscale eddies (100 to $200 \mathrm{~km}$ ) on both sides of the $\mathrm{AzC}$ have been reported (Alves \& Verdière 1999). The small and mesoscale oceanographic features of the region are poorly known. Upwelling phenomena are frequently observed around the Azores islands through highresolution SeaWiFS satellite imagery (A. Martins pers. comm.). The complex bottom topography also causes other oceanographically important phenomena such as jets and/or trapping currents (e.g. Taylor columns) around seamounts.

Water masses. Several water masses occur around the Azores. The North Atlantic Central Water (NACW) is located at depths shallower than $700 \mathrm{~m}$ and is outlined by the permanent thermocline. Beneath the permanent thermocline lie the intermediate waters formed at high latitudes. In the region, northern subpolar waters (Subarctic Intermediate Water [SAIW], the Labrador Sea Water [LSW]) and Antarctic Intermediate Water (AAIW) predominate at intermediate depths. Mediterranean Water (MW) can penetrate into the region at about 800 and $1200 \mathrm{~m}$ (Santos et al. 1995, Johnson \& Stevens 2000).

SAIW and LSW water masses make a major contribution to the characteristics and export of North Atlantic Deep Water (NADW) (Dinter 2001). This water, occurring between about 2000 and $4500 \mathrm{~m}$ (Mann \& Lazier 1996), is the dominant water mass below intermediate depths.

\section{MATERIALS AND METHODS}

Surveys and data. We analyzed the data from longline surveys conducted annually off the Azores Archipelago between 1995 and 2000 (except 1998) by the RV 'Arquipélago'. The sampling design was primarily implemented to estimate annual abundance indices for the demersal ichthyofauna. Most sampling covered depths up to $600 \mathrm{~m}$, but was extended to $1200 \mathrm{~m}$ depth at some stations. All surveys followed a stratified random design; stratification was based on geography and depth (50 $\mathrm{m}$ depth intervals). Areas and sub-areas were defined based on their geographical proximity (e.g. central group of islands) and type (e.g. islands, seamounts). The average number of 30 stations per annual cruise was proportionally allocated according to the size of each area or sub-area (from 0 to $600 \mathrm{~m}$ depth). The station locations were randomly selected within each sub-area.

In all surveys we used the 'long-chain shots' strategy (a long transect), where a continuous length of gear was deployed at 0 to $600 \mathrm{~m}$ (or 0 to $1200 \mathrm{~m}$ at some stations). The sample units were the depth stratum observations within each station. In most years, the data were stratified by $50 \mathrm{~m}$ increments. Different depth stratification was applied for the 1995 survey: $50 \mathrm{~m}$ depth interval at 0 to $200 \mathrm{~m}$ depth; $100 \mathrm{~m}$ depth inter$\mathrm{val}$ at 200 to $600 \mathrm{~m}$ depth; and $200 \mathrm{~m}$ depth interval at 600 to $1000 \mathrm{~m}$ depth. For this reason, the data from the 1995 survey were excluded from some of the analysis presented in this work, and in other cases only the comparable first 4 depth strata (50 m strata) were used. A total of about 620000 hooks were deployed and 145 stations were sampled during the annual longline surveys.

Sampling gear: A standardized longline gear baited with 'chopped salted sardine' was used for all surveys. The longline gear used is identical to the one typically used in the Azorean commercial fishery and is locally known as 'stone/buoy longline'. This gear minimizes the risk of gear loss in the typically rugged bottoms; buoys spaced $74 \mathrm{~m}$ apart float the gear off the bottom and alternate with stones that weight the gear. The longline units (approximately $37 \mathrm{~m}$ long) are termed 'quarter-skate' and contain 25 to 30 J-type hooks no. 9 (Mustad size equivalent with a gape of $12 \mathrm{~mm}$ ) (Menezes 2003).

Biological and fishing data: All fishes caught were sorted and identified to the lowest taxonomic level possible (usually species), counted, weighed, and measured. More detailed biological sampling was conducted on some species. Species catch data, in number and weight, were standardized by effective fishing effort (per 1000 hooks). The effective fishing effort (those hooks that fish effectively) by station and depth stratum was calculated by subtracting the estimated missing hooks (lost or tangled hooks) from the estimated total number of hooks deployed. Estimates of the number of lost hooks were obtained through sampling and classification of the hooks at the time of gear retrieval (for more details, see Menezes et al. 2001). 
In this study, nomenclature, species identification, and auxiliary information on species distribution, zoogeographic affinities, and prey habitats, follow FishBase (Froese \& Pauly 2005), Compagno (1984a,b), Whitehead et al. (1984-1986) and Santos et al. (1997).

Environmental data: Seven abiotic measurements were recorded: longitude, latitude, mean depth, mean temperature, steepness (local bottom slope), irregularity (depth variability) and depth stratum size (horizontal distance between the start and end positions of each depth stratum). Temperature profiles were collected at some stations using expendable bathythermograph probes (XBT). Average temperature depth profiles (50 m interval) were calculated and assumed equal for all stations sampled that year.

Steepness, irregularity and depth stratum size were calculated from data collected during gear deployment. Geographic position and depth were recorded at the beginning of each quarter-skate longline section (QS). This data was then used to estimate the station/depth stratum steepness as follows (in degrees):

$$
\text { steepness }_{i j}=\arctan \left(\frac{50}{L_{i j}}\right) \quad \text { with } \quad L_{i j}=n_{i j} \times \overline{L_{\mathrm{QS}}}
$$

where $50 \mathrm{~m}$ is the constant depth stratum height, $L_{i j}$ is the total estimated horizontal length of the gear deployed at stratum $j$ of station $i, n_{i j}$ is the total number of QSs deployed, and $\overline{L_{\mathrm{QS}}}$ is the estimated mean length of each QS of the longline used, which was assumed to be about $36.5 \mathrm{~m}$ length.

The irregularity index of each station/depth stratum was calculated according to the following expression:

$$
S_{i j}^{2}=\frac{\sum_{m=1}^{n-1}\left(d_{i j m+1}-d_{i j m}\right)^{2}}{n_{i j}-1} \quad \text { irregularity }{ }_{i j}=\frac{S_{i j}^{2}}{\left(d_{i j \max }-d_{i j \min }\right)}
$$

where $S_{i j}^{2}$ is the variance of the successive differences of the depth soundings $d$ of the QSs $m$, divided by the total depth-sounding range $\left(d_{\max }-d_{\min }\right)$ for each stratum $j$ at station $i$. In those cases where only 1 or 2 QS were deployed in a given depth stratum, the irregularity index value was assumed equal to the value of the preceding stratum of that particular station. The type of substrata (e.g. rock, sand, mud) is an important structuring factor that affects the spatial distribution and abundance of the demersal fish fauna. In the absence of this type of auxiliary information, the steepness and irregularity indices can be regarded as proxies for those sea-bed topographic features. Empirically, higher values of the irregularity index are expected for rocky areas and lower values of the steepness index are expected for soft-bottom areas, where sedimentation is expected to be greater.

Analytical methods. Multivariate analysis: We examined the large-scale structure of the demersal fish assemblages by evaluating the similarities between samples and identitying species using 2 multivariate techniques of classification and ordination: the 2-way indicator species analysis (TWINSPAN, Hill et al. 1975) and non-metric multidimensional scaling (MDS), introduced by Shepard (1962, in Clarke \& Warwick 1994) and Kruskal (1964, in Clarke \& Warwick 1994).

To complete these analyses, a pooled 2-way data matrix (station/depth stratum vs species) was built from all 4 survey years (1996, 1997, 1999 and 2000). Species were excluded if they occurred in less than $1 \%$ of the stations. The pelagic species Scomber japonicus was excluded because they are likely caught in the water column during line deployment or retrieval. The final data matrix used in the multivariate analysis resulted in 1364 sampling units $\times 29$ species.

The TWINSPAN classification analysis was completed by applying the routine implemented in the software PC-ORD, ver. 4.25 (developed by McCune \& Mefford 1999). This classification method is a divisive method that classifies sites and species and produces a list of sorted species by station. This allows the identification of groups of stations showing faunal similarities in terms of species composition and relative abundances. Despite some criticism of this method (Clarke \& Warwick 1994, Legendre \& Legendre 2000), TWINSPAN has the advantage of handling a large number of samples without needing to group samples into a manageable number. Final results are displayed in an easy-to-read 2-way table arranged according to station and species similarities. Station clusters can be characterized by their differential species compositions, diversity, total biomass or other ecological features.

The ordination analysis was completed using the MDS routine implemented in the software PRIMER (Plymouth Routines in Multivariate Ecological Research) for Windows ver. 5.2.2 (2001). MDS positions samples in a 2-dimensional space such that the relative distance of the samples reflects their relative similarity/dissimilarity, with samples most similar occurring closer together. With more than 100 samples, the MDS analysis increases the complexity of the sample relationships and a 2-dimensional representation is unlikely to be adequate (Clarke \& Warwick 1994). In this study, 2 MDS ordinations were performed. As suggested by Clarke \& Warwick (1994), the initial large data sets were sub-divided a priori on the basis of the subsets obtained from the TWINSPAN classification analysis. The samples within each group (clusters of sample sites at the 4th TWINSPAN dichotomy level) were averaged and then input to the MDS to display 'large-scale' structures. In a second ordination, all observations (sampling units) within each of the 4 main groups obtained at the 2nd TWINSPAN dichotomy level were analysed separately (without averaging) to display any 'small-scale' structures. 
All biotic station similarity matrices used in the MDS were constructed using the Bray-Curtis similarity index (Clifford \& Stephenson 1975). Because the longline catches and the sampling fishing efforts allocated in each station/depth-stratum combination were, in general, highly variable, the data were standardized (each species abundance divided by the total sample) and $\log (x+1)$ transformed.

Interpretation techniques: Fish assemblages (site groups) emerging from the TWINSPAN analysis are characterized by homogeneous faunal composition. Each group can be distinguished not only by their differential species composition but also by their typifying species. The Indicator Values (INDVAL) method (Dufrene \& Legendre 1997) implemented in PC-ORD ver. 4.25 was used to identify those typifying species for each group at the 4th TWINSPAN dichotomy level.

The relationship between the biotic MDS configuration and the environmental data was analyzed with the BIO-ENV procedure (Clarke \& Ainsworth 1993) implemented in PRIMER. Two analyses were performed at 2 different levels of data aggregation and, therefore, at 2 different levels of the assemblage structure. One analysis was conducted on the average similarity matrix at the 4 th TWINSPAN dichotomy level groups ('large-scale' structure), and the second was performed separately for each of the 4 main clusters (at the 2nd TWINSPAN dichotomy level), using all withingroup similarities ('small-scale' structure). This analysis consists of choosing a subset of environmental variables that provides the best match with the biotic MDS ordination of the samples. The strength of agreement between the biotic and abiotic samples dis/similarity matrices was determined by the Spearman rank correlation coefficient (Clarke \& Warwick 1994). The environmental dissimilarity matrices used in the BIO-ENV analysis were calculated with the normalized Euclidean distance, which seems more appropriate for environmental data (Clarke \& Warwick 1994).

\section{RESULTS}

\section{Taxonomy and abundance}

A total of 44881 fish (weighing a total of $41968 \mathrm{~kg}$ ) and representing 104 species belonging to 49 families were caught in surveys from 1995 to 2000 . Teleost fishes were caught in large numbers comprising 78 species from 39 families, while elasmobranchs comprised only 26 species belonging to 10 families (Appendix 1, available at www.int-res.com/articles/suppl/m324p241_app.pdf in MEPS Supplementary Material). Among the 39 families identified, the Scorpaenidae and the Moridae families were represented by the largest number of species, with 6 species each. Among the 10 elasmobranch families, the Dalatiidae was the best represented, with 10 species, followed by the Centrophoridae and the Rajidae, with 4 species each. About $51 \%$ of the species were benthic, $39 \%$ benthopelagic and only $10 \%$ pelagic (Fig. 2, Appendix 1). The number of benthic and pelagic species generally decreased from shallow to deep waters, whereas the number of benthopelagic species increased in the deeper strata, dominating below $800 \mathrm{~m}$ depth. Most species were classified as subtropical (51\%) and mainly from the Eastern Atlantic and Mediterranean areas $(33 \%)$ (Figs. $3 \& 4$ ). Those species with broad geographical distributions (i.e. a 'wide distribution', Appendix 1) dominated the deepest strata, while the proportion of subtropical species was higher in shallower waters, greatly decreasing with depth.

According to the assumed distribution patterns of their preys (Fig. 5, Appendix 1), most of the species caught feed on benthopelagic species (45\%). The importance of the epibenthos preys decreased in the deepest strata, whereas the proportion of fishes that feed on pelagic and benthopelagic preys increased in the deepest strata.

In addition, the species were classified according to their relative abundance and relative frequency of
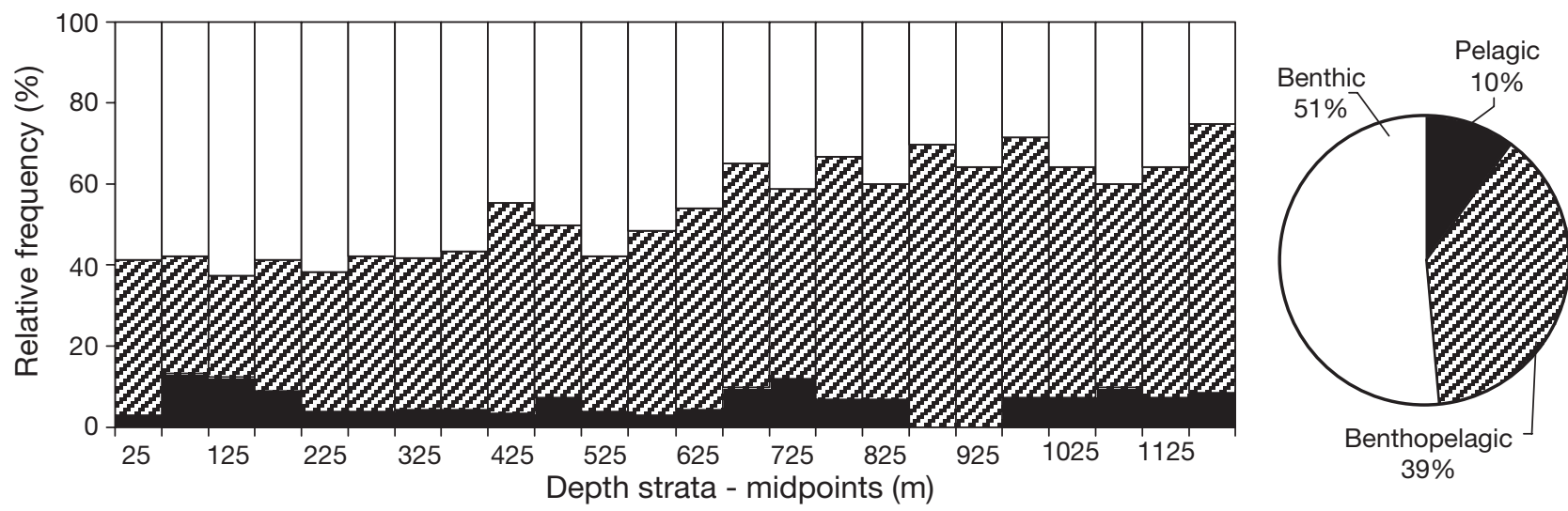

Fig. 2. Species lifestyles in each depth strata and in the total catch 

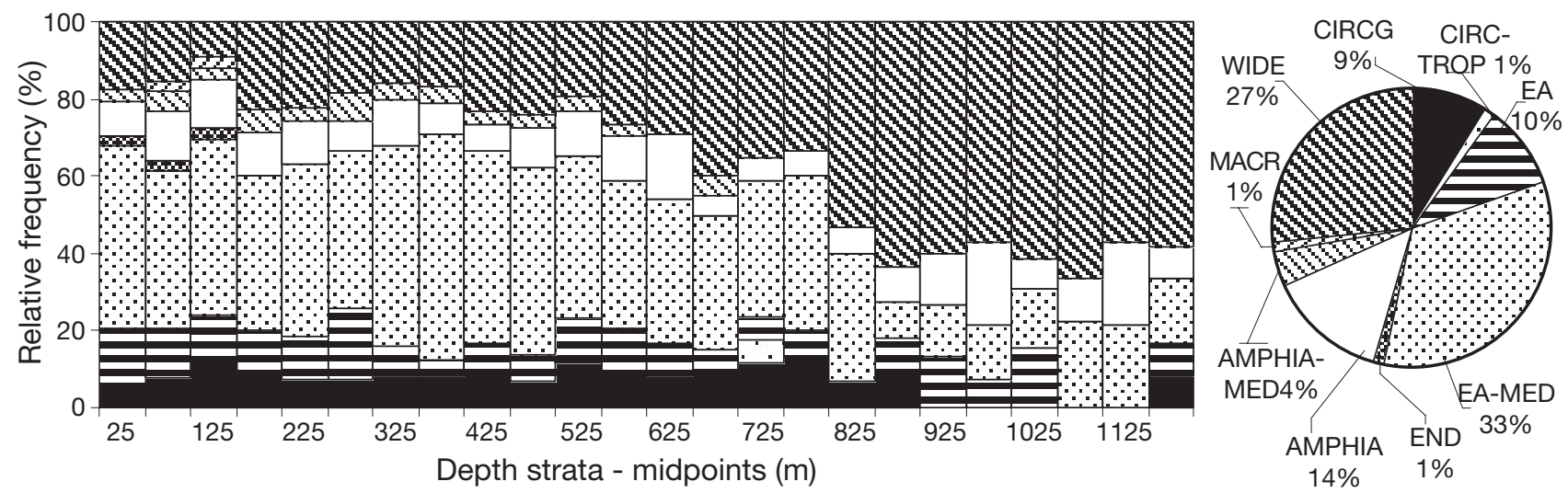

Fig. 3. Species distribution patterns in each depth strata and in the total catch. Areas indicated: CIRCG - circumglobal; CIRC-TROP - circumtropical; EA - Eastern Atlantic; MED - Mediterranean; END - endemic; AMPHIA - amphiAtlantic; MACR- Macaronesian; WIDE - wide distribution
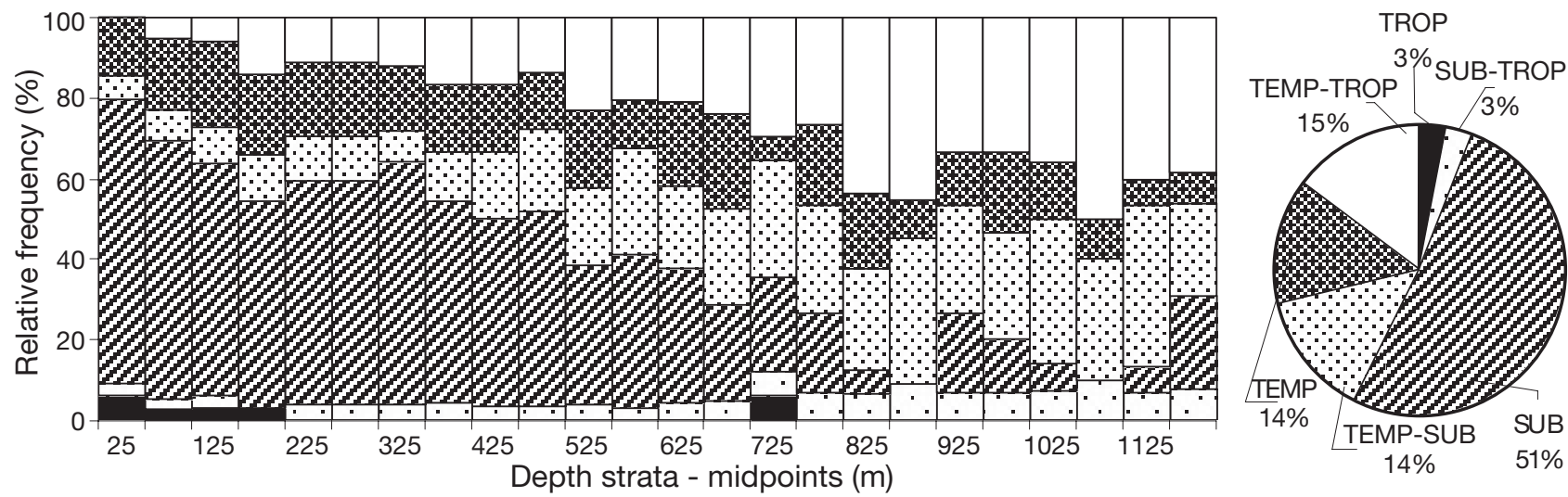

Fig. 4. Species climate origin in each depth strata and in the total catch. Climates indicated: TROP - tropical; SUB - subtropical; TEMP - temperate
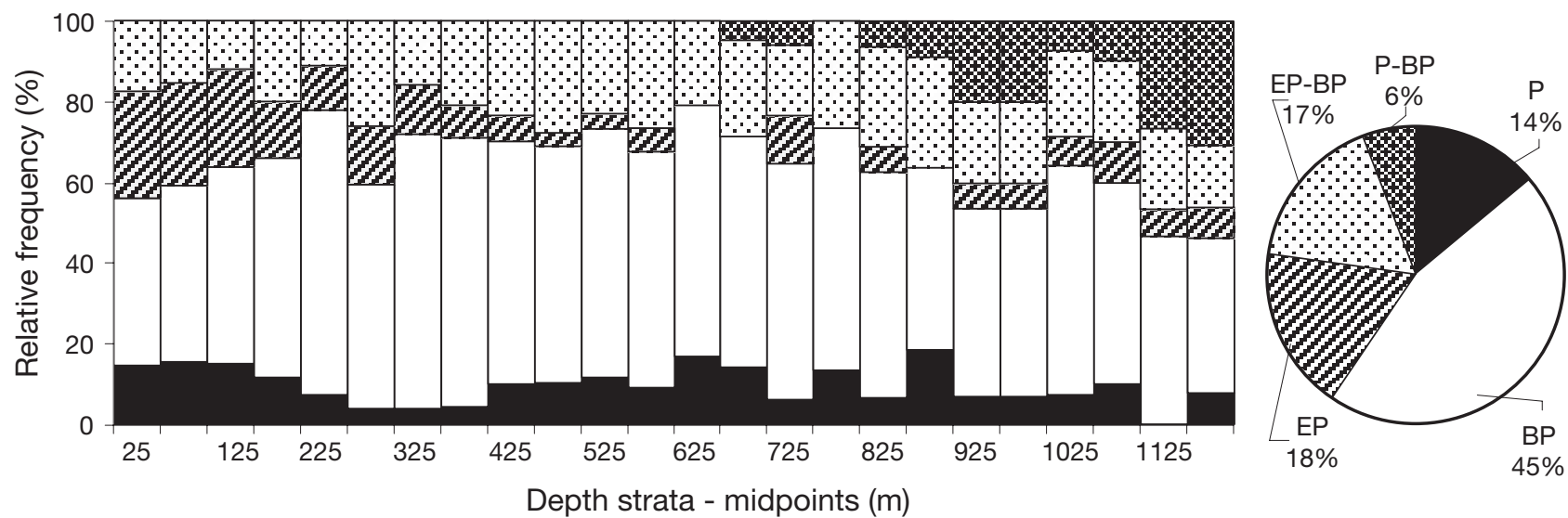

Fig. 5. Species major prey groups in each depth strata and in the total catch. Prey groups indicated: EP - epibenthic; BP benthopelagic; $\mathrm{P}$ - pelagic

occurrence (Appendix 1). Dominant species (Group A) include only 3 species - Mora moro, Helicolenus dactylopterus dactylopterus hereafter called Helicolenus d. dactylopterus) and Pagellus bogaraveo-each accounting for more than $10 \%$ of the total abundance, and an average frequency of occurrence higher than $25 \%$. Frequent species (Group B) present moderate abundances and include 34 species with relative abundance values between 0.1 and $10 \%$ and with an average frequency of occurrence between 1 and 10\%. Com- 
mon species (Group C) includes 32 species with average relative abundance values between 0.1 and $0.01 \%$. A fourth group of rare species (Group D) was also considered, and includes about 32 species with relative abundances smaller than $0.01 \%$.

In general, more abundant species have higher frequency of occurrence and wider distributions. Dominant species appeared in all 6 areas surveyed, frequent species usually appeared in more than 3 of the 6 areas surveyed (Appendix 1) and the common and rare species occurred only in 1 or 2 of the areas surveyed. Some of the most abundant species, however, were restricted to specific areas. Pagellus acarne and Diplodus sargus were never caught in the seamount areas (Areas 1, 4 and 5), while Pagrus pagrus was never caught in the Princesa Alice bank (Area 1, Sub-area: PAL). The deep-water species Phycis blennoides and Etmopterus spinax also were never caught in Area 6 (Western island group; Appendix 1). About 25 species were caught only once, and the highest number of unique records was observed in the southern area (Area 6, S. Miguel and Santa Maria islands), with 10 unique records (Appendix 1).

\section{Species depth distribution patterns}

In the shallowest depth stratum, many species have similar abundances, while in deep waters 1 or 2 species clearly dominate the catch (Fig. 6). The contribution of all the other species ('Others') comprises about $30 \%$ in the first 4 depth strata and then strongly decreases along a depth gradient. At intermediate depths, Helicolenus d. dactylopterus dominated, while in the deepest strata Mora moro strongly dominated the catch. The clinal change in the species composition shows a clear vertical zonation over the surveyed depths (Fig. 7). At the very first depth strata the species Diplodus sargus cadenati was caught in larger proportions. The species Pagrus pagrus assumes its greatest contribution in the interval 50 to $100 \mathrm{~m}$. Below this shallower strata, the species that most contributed to the total catch were Pagellus bogaraveo (between 50 and $200 \mathrm{~m}$ depth), H. d. dactylopterus (between 275 and $675 \mathrm{~m}$ depth) and M. moro (between 700 and $1200 \mathrm{~m}$ depth). Shelf species occupy narrower depth ranges than slope species, and most species have

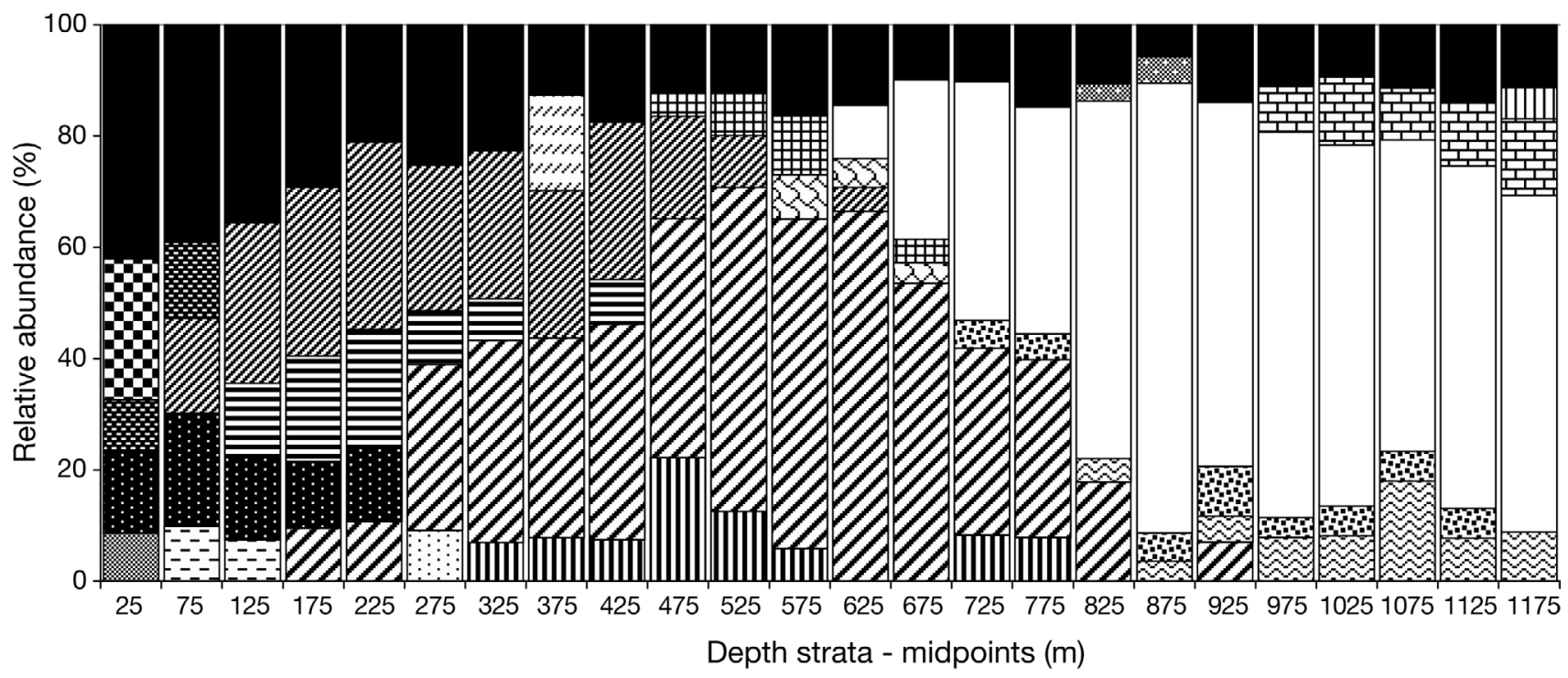

Phycis phycis Diplodus sargus Pagrus pagrus Scomber japonicus Pagellus acarne

Helicolenus d. dactylopterus Beryx decadactylus Etmopterus spinax Etmopterus pusilus Mora moro

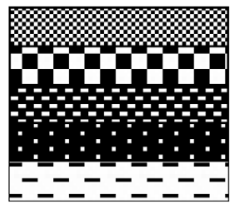

Trachurus picturatus Pontinus kuhlii Pagellus bogaraveo Lepidopus caudatus Beryx splendens

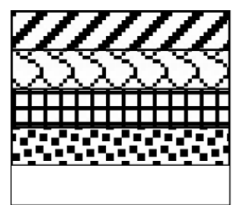

Synaphobranchus kaupii Deania cf. calcea Deania profundorum Centroscymnus crepidater Others
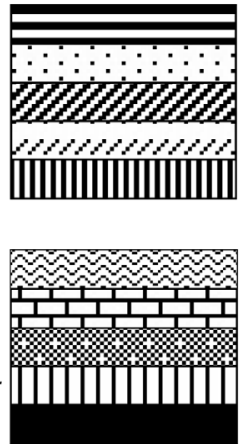

Fig. 6. Total relative number of the top 4 species in each depth strata. The group 'Others' includes all other species caught during the Azores surveys 


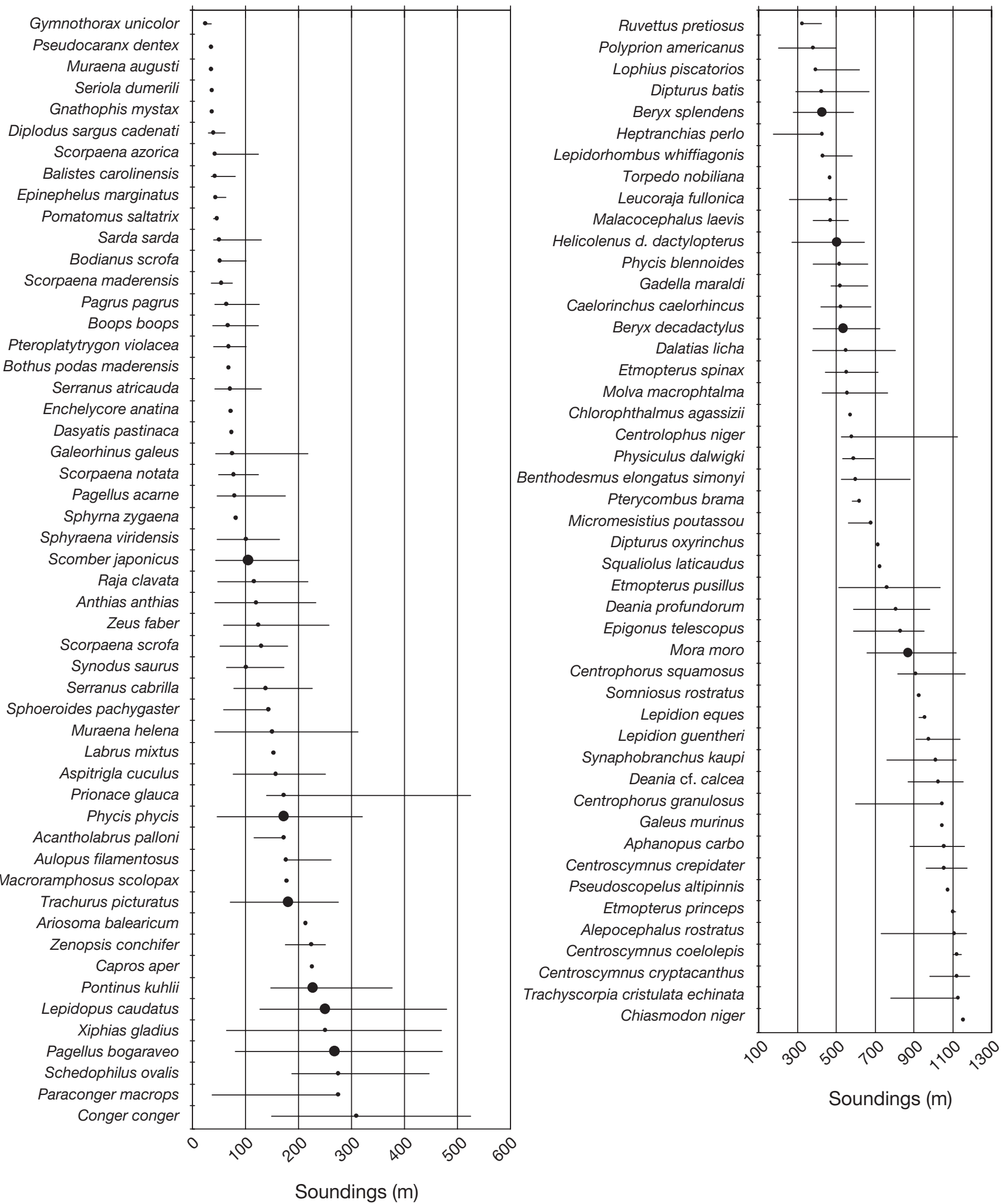

Fig. 7. Individual bathymetric distribution of all fish species caught. Median-weighted depth distribution ( $\pm 80 \%$ percentile) obtained from the Azores cruise surveys. Median values are weighted by species-abundance data. The 10 most abundant species are represented by larger circles 
skewed depth distributions (Fig. 7). For those species occurring in deeper strata, the maximum depths of their distributions are not necessarily the observed values, due to the maximum survey depth (1200 m).

The depth profiles of all species abundance and biomass indices (Fig. 8) follow very similar distribution patterns and have significant decreasing trends with increasing depth (abundance: $r_{\mathrm{s}}=-0.87, \mathrm{p}<0.001$; biomass: $\left.r_{\mathrm{s}}=-0.48, \mathrm{p}<0.05\right)$. The highest abundance values were observed in the 25 to $600 \mathrm{~m}$ interval, followed by a decrease in the 600 to $925 \mathrm{~m}$ interval, and a small peak at the 950 to $1000 \mathrm{~m}$ depth stratum. The relative values of biomass below $950 \mathrm{~m}$ depth were relatively larger than those of abundance, reflecting an increase in the mean individual weight of the deeper fish species caught.

\section{Fish assemblage structure and zonation}

The TWINSPAN classification analysis primarily classified samples according to depth (Table 1, Fig. 9). The first dichotomy level separates all samples shallower than $500 \mathrm{~m}$ (Groups S13 to IS20) from other deeper samples (Groups ID21 to D28). At the second dichotomy level, the shelf and shelf-break samples (<250 m depth, Groups S13 to S16) are separated from the upper-slope samples (250 to $650 \mathrm{~m}$ depth, Groups IS17 to IS20). At the same dichotomy level samples of the mid-slope zone (between 650 to $800 \mathrm{~m}$, Groups ID21 to ID24) are separated from the deep mid-slope samples below the $800 \mathrm{~m}$ depth (Groups D25 to D28). Three of the 4 main assemblages are well delineated along the depth gradient. The deep intermediate assemblage (mid-slope ID groups) is less distinct and largely overlaid with the upper-slope and deep midslope groups, with a peak of observations at 700 to $800 \mathrm{~m}$ depth (Fig. 9).

The MDS ordination analysis (Fig. 10) revealed a large-scale structure corresponding to that found in the classification analysis. The clear separation of the main assemblages displayed in the horizontal gradient represented in the first axis of the MDS plot is by far the most important. Results of the BIO-ENV analysis (not shown) confirm that depth and temperature variables explain well the main biotic assemblage ordination (along the MDS horizontal axis), both with Spearman rank correlations of about 0.90 . The Spearman rank correlations obtained for the stratum size, bottom irregularity and steepness vary between 0.33 and 0.16 . The abiotic variable combination (depth/

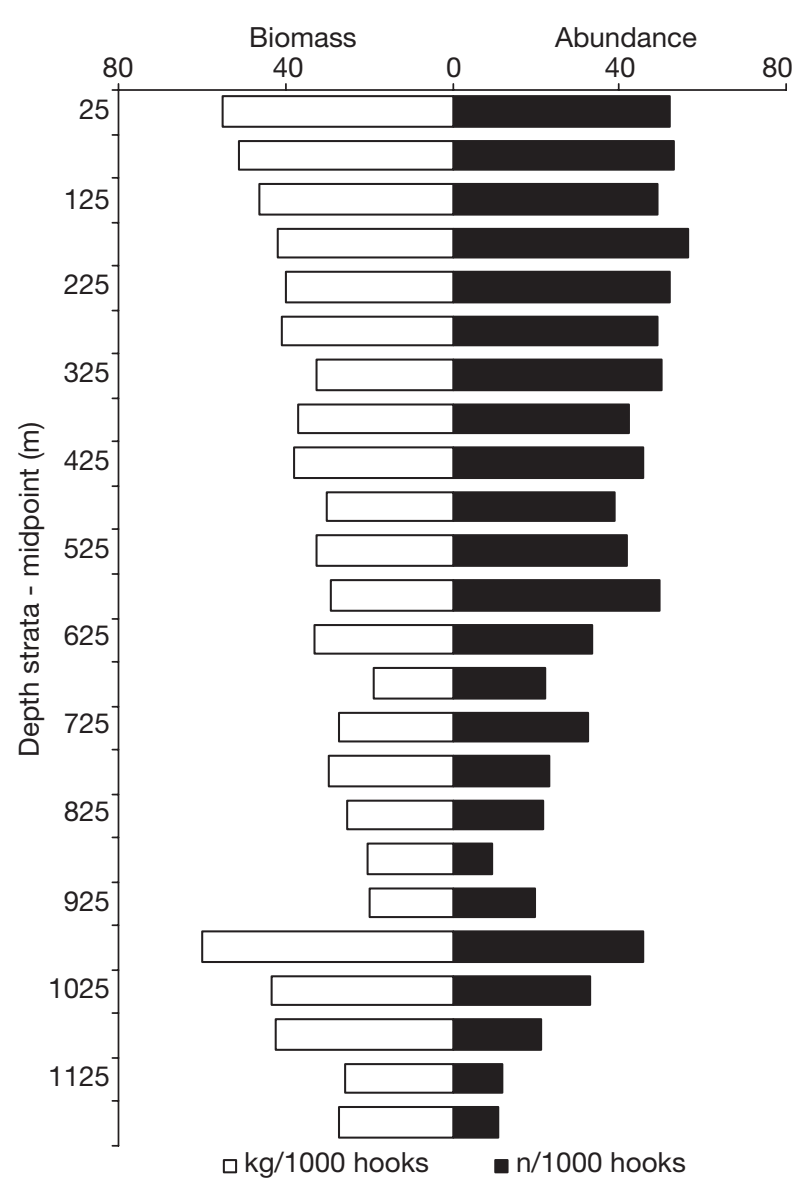

Fig. 8. Total median species abundance (no. per 1000 hooks) and biomass (kg per 1000 hooks) indices by depth strata, from the Azores longline cruise surveys (1995 to 2000)

temperature) that best matches the biotic ordination structure shows a correlation value of 0.906 . The average similarity between all samples within each main assemblage shows an increasing trend from the shal-

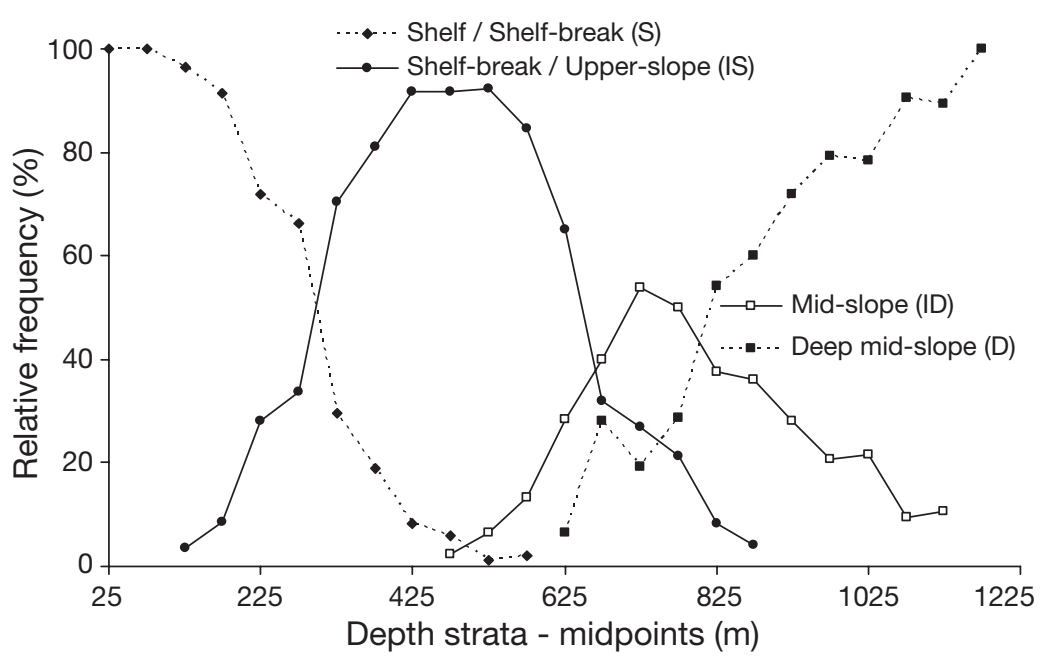

Fig. 9. Relative frequency of samples within the main 4 assemblages at the 2nd TWINSPAN dichotomy level by depth strata 


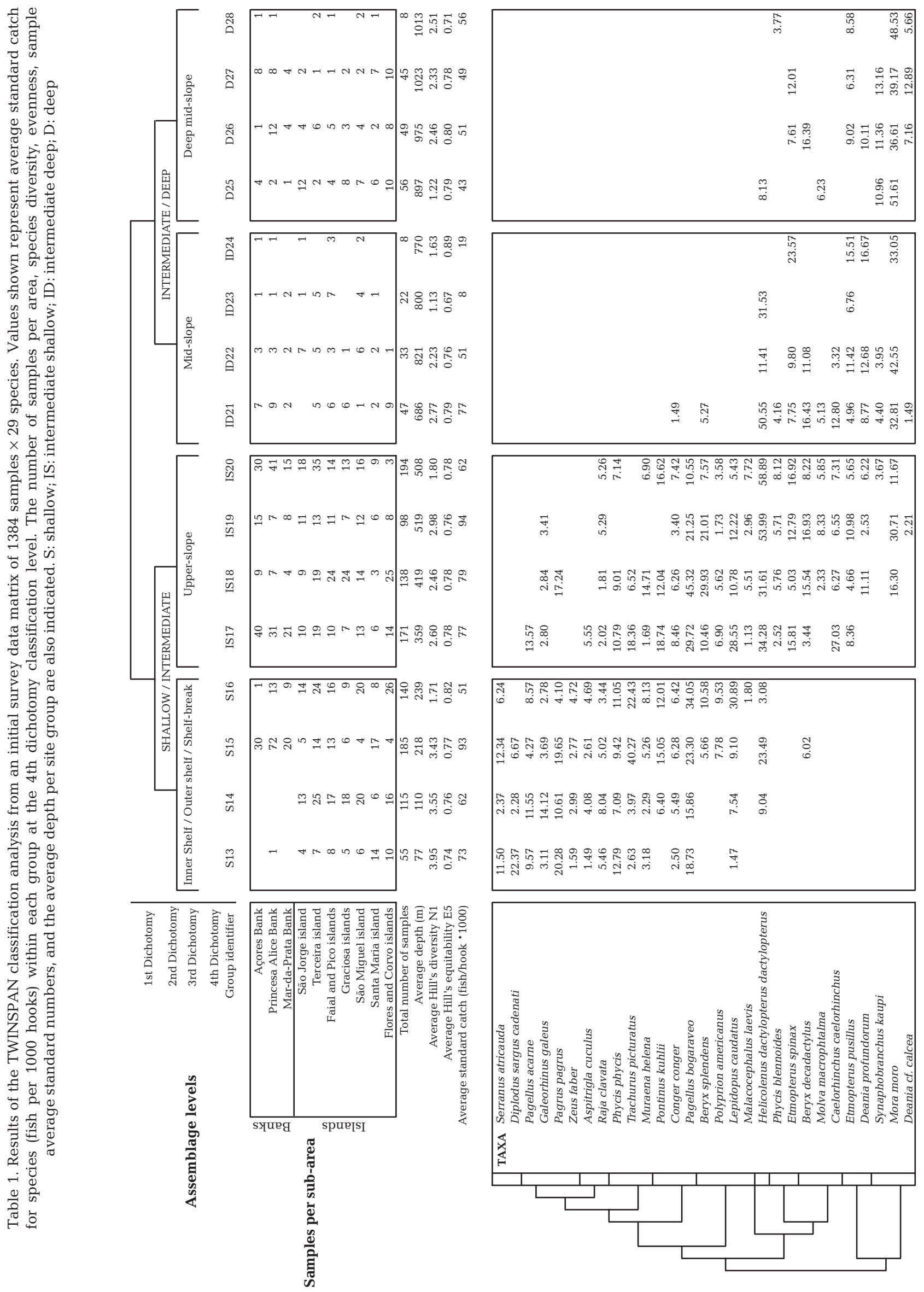


MDS of station groups - species abundance

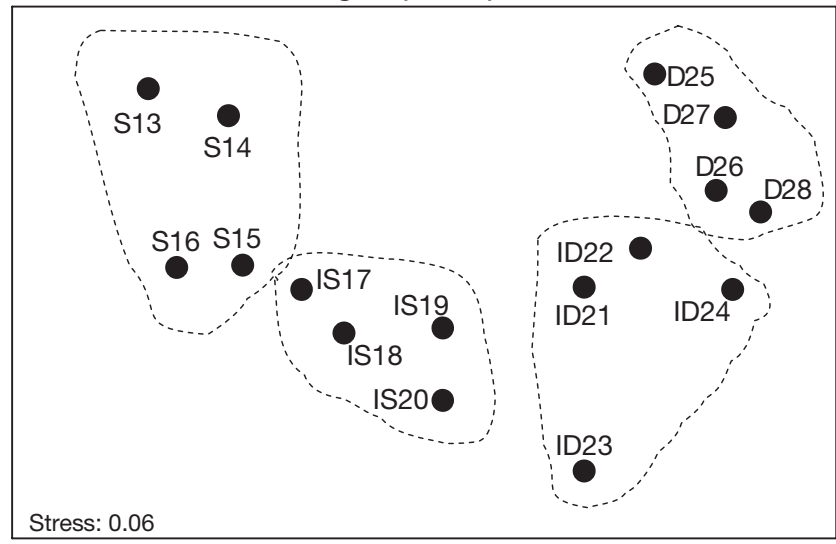

Temperature $\left({ }^{\circ} \mathrm{C}\right)$
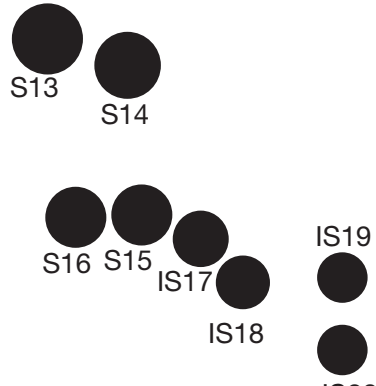

IS20

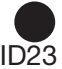

Average depth (m)

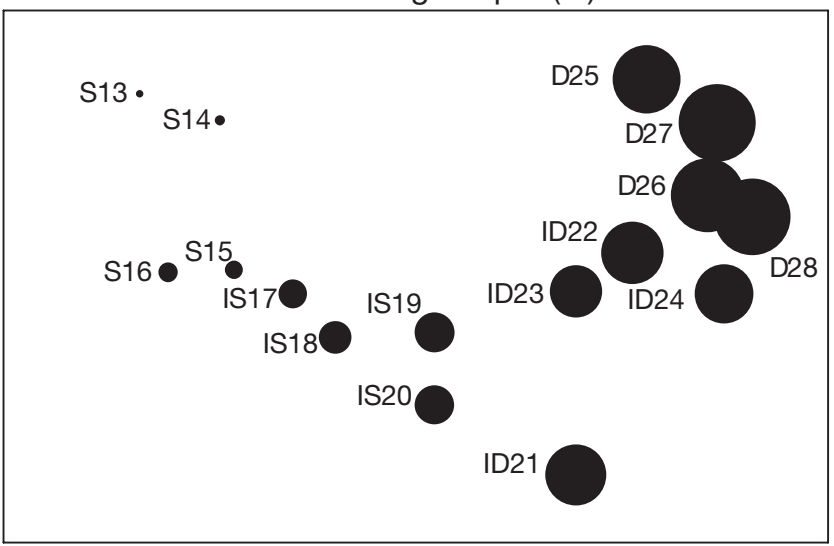

Irregularity

$\mathrm{S} 13$ $\mathrm{S} 1 \dot{4}$

$\mathrm{D} 25$

D27
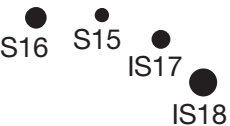

IS19

ID21

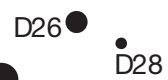

ID22

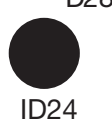

IS20

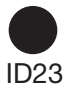

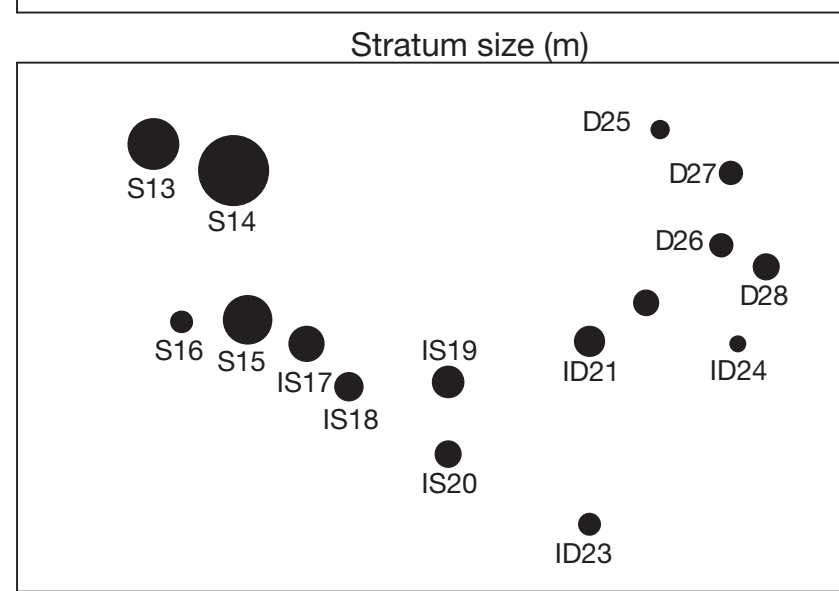

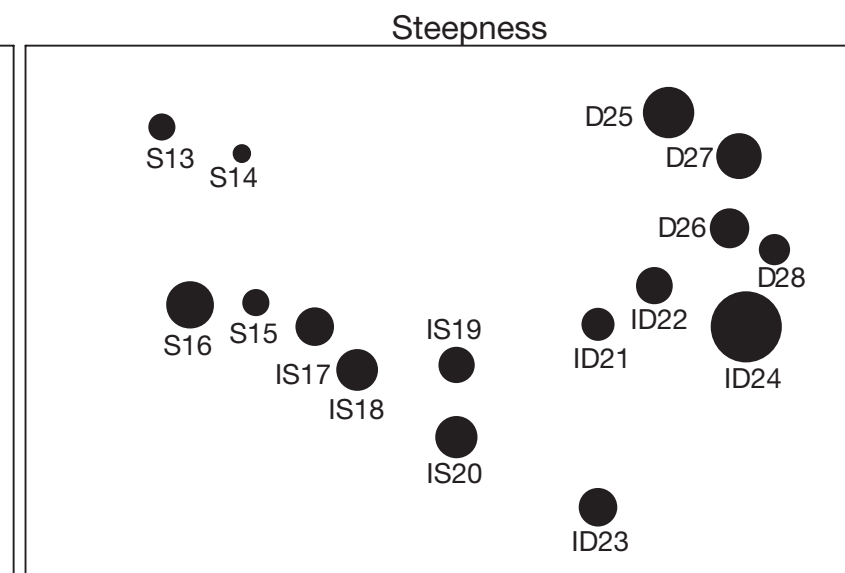

Fig. 10. MDS (non-metric multi-dimensional scaling) ordination of the average matrix at the 4th TWINSPAN dichotomy level classification. The main assemblage structure at the 2nd dichotomy TWINSPAN level (encircled) is represented in the uppermost left plot. The same MDS ordination, but superimposed with the average values of the environmental variables, is represented in the other 5 plots. Size of symbols is proportional to the value of the variables. Major assemblages are identified as follows: S, shallow; IS, shallow intermediate; ID, intermediate deep; D, deep

lower to the deeper assemblages (S - 30.44\%, IS $38.98 \%$, ID $-36.71 \%$ and D $-56.3 \%$ ). This indicates an increasing homogeneity in the species composition of the samples along the depth gradient.

The assemblages obtained at the 4 th TWINSPAN dichotomy level were analyzed in more detail, but their ecological interpretation is less obvious. The correlation values obtained from the BIO-ENV analyses run separately for each of the main assemblages at the 2nd TWINSPAN dichotomy (not shown), are smaller and decrease from shallow to deep assemblages. For all cases, depth and/or temperature explain the majority of the 
Table 2. Results of the Monte Carlo test of significance of the observed maximum indicator values (IV) for each species (based on 1000 permutations). The groups at the 4th TWINSPAN dichotomy level with maximum observed indicator values (IVs) are identified (Maxgrp). The standard deviation (SD) and the p-values of IVs are also given for each species. * Proportion of randomized trials with indicator value (IV) equal to or exceeding the observed indicator value. $\mathrm{p}=(1+$ number of runs $\geq$ observed $) /(1+$ number of randomized runs $)$

\begin{tabular}{|c|c|c|c|c|c|}
\hline \multirow[t]{2}{*}{ Taxa } & \multirow[t]{2}{*}{ Maxgrp } & \multirow{2}{*}{$\begin{array}{l}\text { Observed } \\
\text { Indicator } \\
\text { Value (IV) }\end{array}$} & \multicolumn{3}{|c|}{$\begin{array}{l}\text { IV from } \\
\text { randomized groups }\end{array}$} \\
\hline & & & Mean & $\mathrm{SD}$ & $\mathrm{p}^{*}$ \\
\hline Phycis phycis & $\mathrm{S} 13$ & 30.10 & 4.20 & 2.44 & 0.001 \\
\hline Serranus atricauda & $\mathrm{S} 13$ & 65.70 & 2.80 & 2.49 & 0.001 \\
\hline Muraena helena & $\mathrm{S} 13$ & 11.00 & 2.40 & 1.84 & 0.009 \\
\hline Pagrus pagrus & $\mathrm{S} 13$ & 59.00 & 3.20 & 2.32 & 0.001 \\
\hline Diplodus sargus cadenati & S13 & 54.00 & 2.30 & 2.15 & 0.001 \\
\hline Pagellus acarne & $\mathrm{S} 14$ & 37.10 & 3.10 & 2.32 & 0.001 \\
\hline Aspitrigla cuculus & S14 & 24.70 & 2.70 & 2.45 & 0.002 \\
\hline Galeorhinus galeus & S14 & 39.40 & 3.20 & 2.57 & 0.001 \\
\hline Zeus faber & S14 & 7.80 & 2.20 & 2.17 & 0.032 \\
\hline Raja clavata & S14 & 47.70 & 3.30 & 2.53 & 0.001 \\
\hline Pontinus kuhlii & S15 & 44.80 & 4.00 & 2.52 & 0.001 \\
\hline Conger conger & S15 & 15.80 & 4.30 & 2.38 & 0.006 \\
\hline Trachurus picturatus & S15 & 41.10 & 4.20 & 2.95 & 0.001 \\
\hline Pagellus bogaraveo & $\mathrm{S} 16$ & 22.90 & 6.60 & 2.38 & 0.003 \\
\hline Polyprion americanus & IS17 & 5.50 & 2.50 & 2.13 & 0.087 \\
\hline Lepidopus caudatus & IS17 & 13.90 & 3.90 & 2.77 & 0.015 \\
\hline Beryx splendens & IS18 & 69.30 & 4.20 & 2.59 & 0.001 \\
\hline Phycis blennoides & IS19 & 10.80 & 2.70 & 2.14 & 0.012 \\
\hline Beryx decadactylus & IS19 & 44.30 & 3.30 & 2.31 & 0.001 \\
\hline Molva macrophtalma & IS19 & 6.00 & 2.10 & 2.03 & 0.052 \\
\hline Caelorinchus caelorhincus & IS19 & 12.10 & 2.30 & 2.14 & 0.009 \\
\hline Malacocephalus laevis & IS19 & 4.20 & 2.40 & 2.49 & 0.139 \\
\hline Helicolenus d. dactylopterus & S IS20 & 22.20 & 6.60 & 2.16 & 0.002 \\
\hline Etmopterus spinax & IS20 & 13.40 & 3.50 & 2.36 & 0.009 \\
\hline Deania profundorum & ID22 & 61.60 & 2.50 & 2.28 & 0.001 \\
\hline Etmopterus pusillus & ID24 & 39.30 & 2.90 & 2.15 & 0.001 \\
\hline Mora moro & D25 & 21.00 & 4.00 & 2.56 & 0.003 \\
\hline Synaphobranchus kaupii & D26 & 63.40 & 2.80 & 2.42 & 0.001 \\
\hline Deania cf. calcea & D27 & 62.60 & 2.70 & 2.21 & 0.001 \\
\hline
\end{tabular}

correlations with species data, and the addition of other variables - though providing statistically better solutions - minimally improves the overall correlations.

Without other auxiliary information to better characterize the stations sampled, no extra inferences can be made on the influence of other environmental variables affecting the biotic assemblage structures obtained. However, a literature review (Whitehead et al. 1984-1986, Froese \& Pauly 2005) on the habitat preferences of their member species give further inferences on the environmental determinants of the smallscale assemblages obtained. In agreement with previous findings, additional smaller fish assemblages can be considered, within the most diverse and heterogeneous shallower main assemblage, as having some ecological coherence. The shallower assemblages S13 and S14 are mainly composed of island shelf samples, while S15 has a significant proportion of seamount (banks) shallow samples and S16 has sites with high steepness. The resulting assemblage structure proposed comprises 7 groups.

In the shelf and shelf break within the euphotic zone (above $\pm 200 \mathrm{~m}$ ), 4 groups were identified (see Table 1). An inner-shelf-island, hard-bottom assemblage (G1: S13), an outer-shelf-island, soft-bottom assemblage (G2: S14), a seamount/island-shelf/shelf-break assemblage (G3: S15) and finally a transitional shelf/break assemblage (G4: S16). The other 3 assemblages recognized correspond to the deeper major groups obtained at the 2nd TWINSPAN dichotomy level. In this case the smaller assemblages at the 4th TWINSPAN dichotomy level within these major groups were not considered separately, due to the overall higher homogeneity of their sample sites and thus a higher similarity in the ecological conditions. We consider an intermediate shallow upperslope assemblage (G5: IS17 to IS20), an intermediate mid-slope assemblage (G6: ID21 to ID24), and a deep mid-slope assemblage (G7: D25 to D28) (Table 1).

From the relative abundance of the main species that characterize assemblage G1, and according to their habitat preferences, this assemblage can be regarded as composed of species found on island shelves in shallower waters and predominantly in rocky/hard bottom biotopes. This group includes 55 island, shallow samples and only 1 bank-area sample distributed at an average depth of $77 \mathrm{~m}$. The most important species with significant indicator values (IVs) that typify this assemblage are Pagrus pagrus, Diplodus sargus cadenati, Phycis phycis and Serranus atricauda (Table 2, Fig. 11). Other common species of this group include Muraena helena, Pagellus bogaraveo and Conger conger, among a total of 33 species caught in this group of samples. The average diversity is relatively high (Table 1): about 25 species are common to other assemblages and only 8 species are unique to this group.

The samples of assemblage G2 were distributed at an average depth of $110 \mathrm{~m}$. This assemblage is also typical of island shelf waters, since it includes only island shore samples. From the relative abundance of the main species caught and according to their habitat preferences, this assemblage can be regarded as mainly composed of species typical of sandy or softbottom habitats of the island inner/outer shelves. This is the case for the significant typifying species of this 


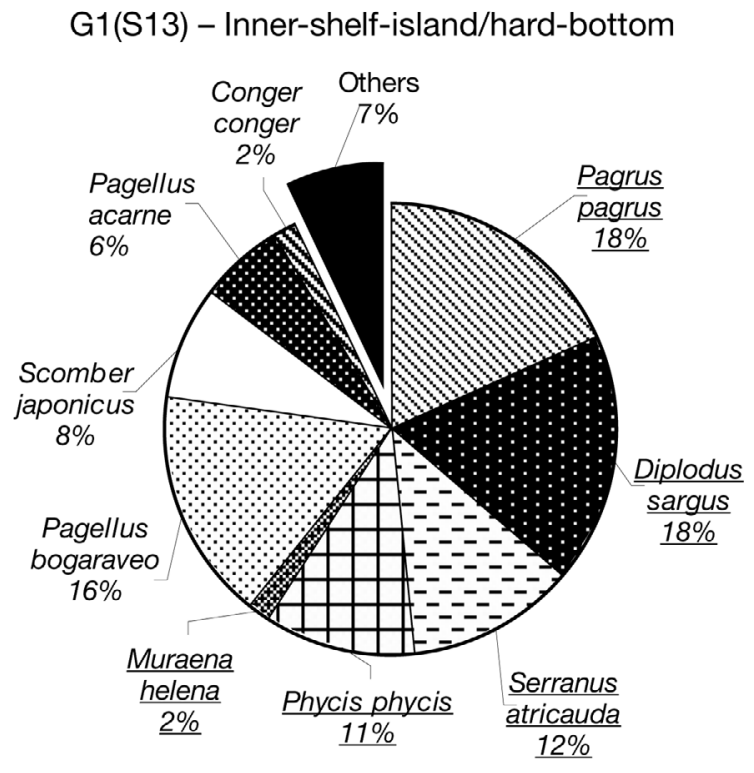

G3(S15) - Bank shallow/Shelf-break transitional

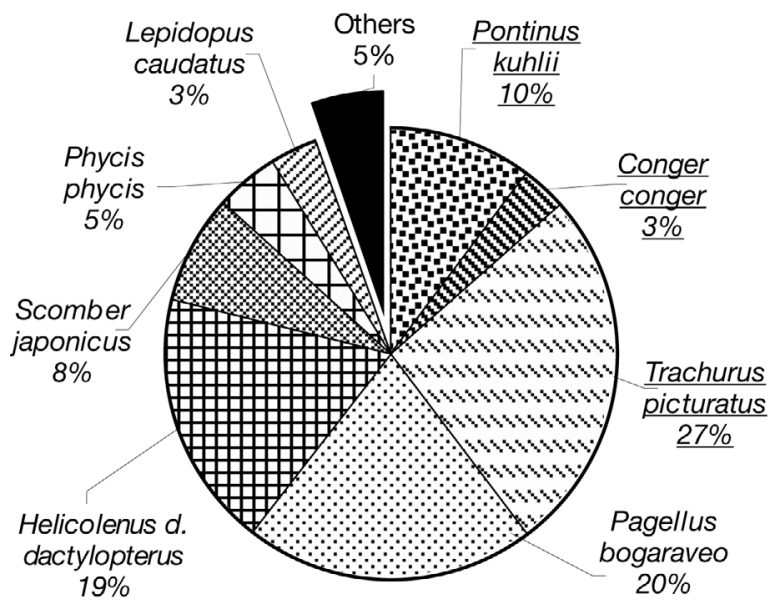

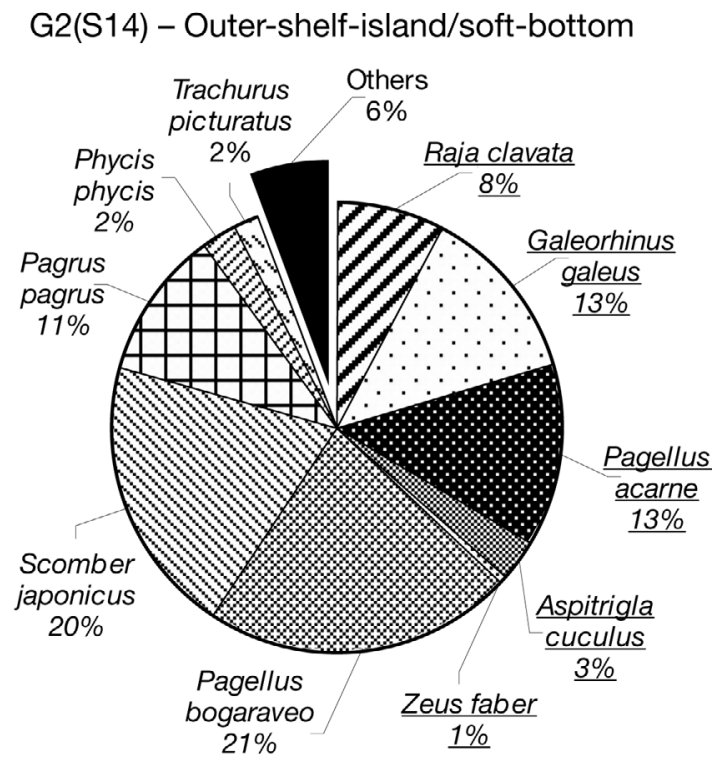

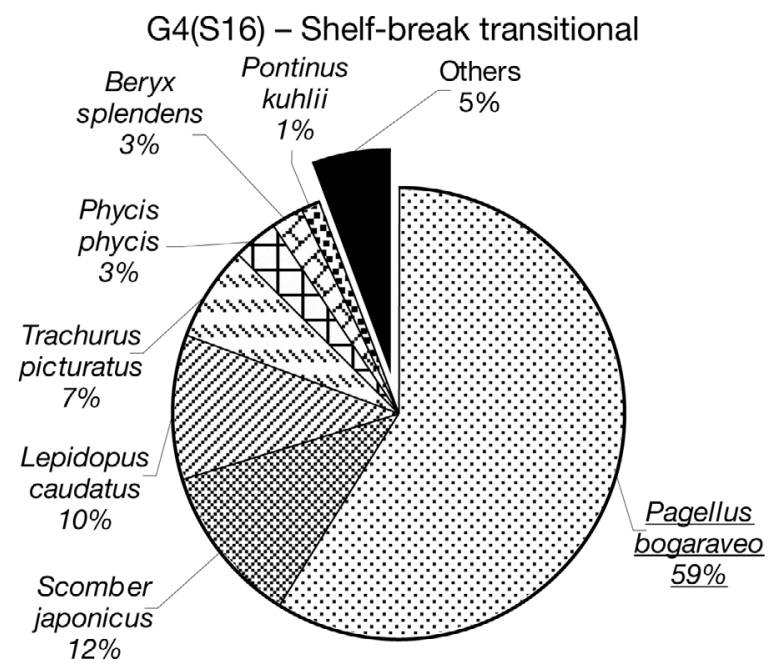

Fig. 11. Relative abundance of indicator species (underlined) and some other common species (not underlined) within each assemblage (Groups G1 to G4)

assemblage, such as Pagellus acarne, Galeorhinus galeus, Raja clavata, Aspitrigla cuculus and Zeus faber (Table 2, Fig. 11). About 40 fish species were caught in this group, and the average diversity was the second highest of all groups considered (Table 1).

Assemblage G3 is mainly composed of shallower seamount samples, although there are also shallow island samples in this group. It includes the first depth strata $(0$ to $50 \mathrm{~m})$ samples of the seamount sub-area PAL (the Princesa Alice bank in Area 1). This is 1 of 2 seamounts in the Azores with shallow summits penetrating the euphotic zone, and where some islandubiquitous shelf species such as Pagrus pagrus, Pagellus acarne and Diplodus sargus cadenati were never found. Samples were distributed at an average depth of $218 \mathrm{~m}$ and can be regarded as typical of shallow/ shelf-break waters of shallower seamounts and island shore sites. The typifying species of this assemblage are Pontinus kuhlii, Trachurus picturatus (adults) and Conger conger (Table 2, Fig. 11). About 32 fish species were caught at these sample sites, and the average diversity was relatively high (N1: 3.43, Table 1). The last shelf and shelf-break assemblage suggested is assemblage G4. As for assemblage G3 it is also at a shelf-break transitional depth, and the major difference between them is the predominance of island and high steepness sample sites (Fig. 10). The species Pagellus bogaraveo (Fig. 11) is the unique significant typifying species of this transitional group (Table 2). Other species found at these sites are 


\section{G5(IS) - Intermediate upper-slope}
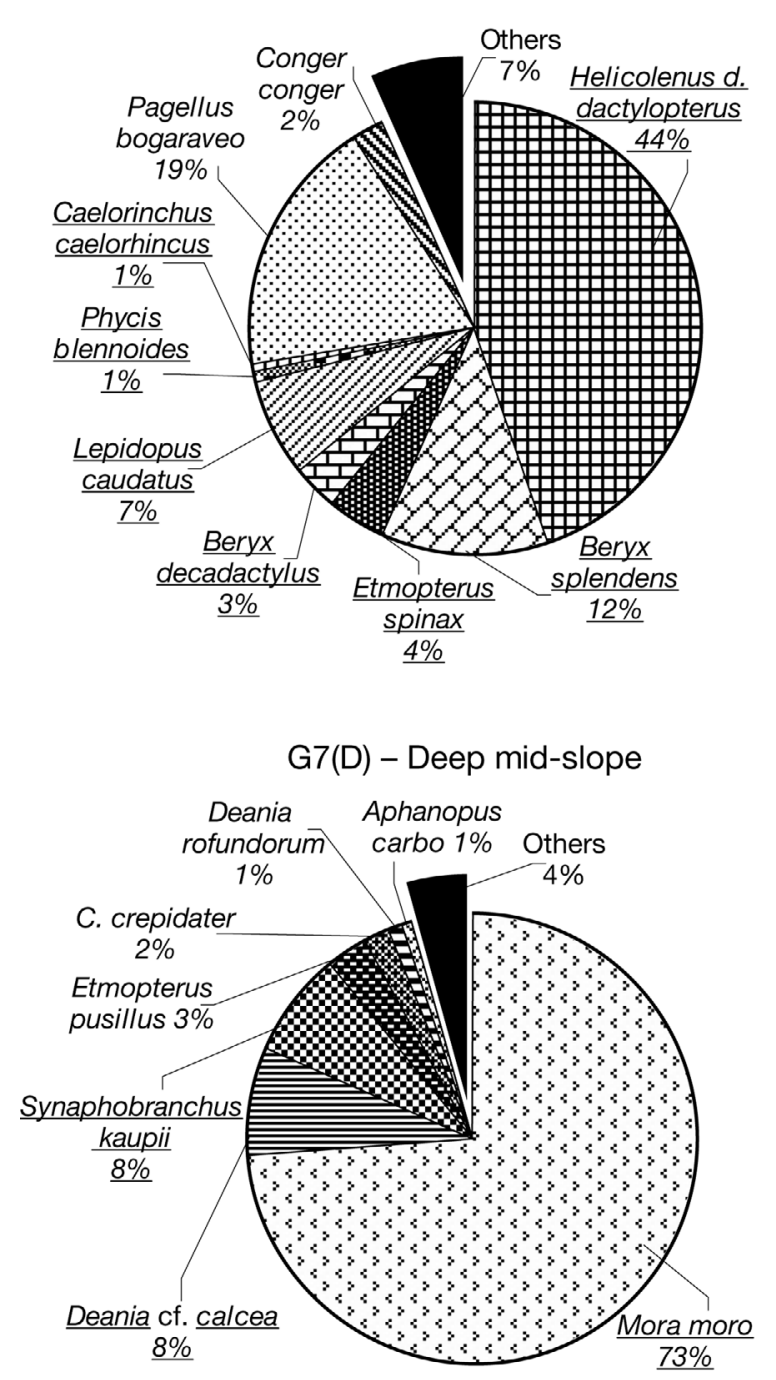

benthopelagic with schooling behavior (e.g. T. picturatus and Lepidopus caudatus).

Assemblage G5 includes a larger number of sample sites, also widely distributed geographically from both seamount and island flanks. Indicator species of this assemblage are Beryx splendens, Beryx decadactylus, Helicolenus d. dactylopterus, Etmopterus spinax, Lepidopus caudatus, Phycis blennoides and Caelorinchus caelorhincus (Table 2, Fig. 12). Samples were distributed at an average depth of $447 \mathrm{~m}$. This upper-slope group can be considered to be an intermediate/ transitional assemblage, with species from the shelf break at one extreme and species from the mid-slope and deep-mid slope at the other. This group is composed of a high number of species, some of them the most abundant and commercially important in the Azores demersal fishery.

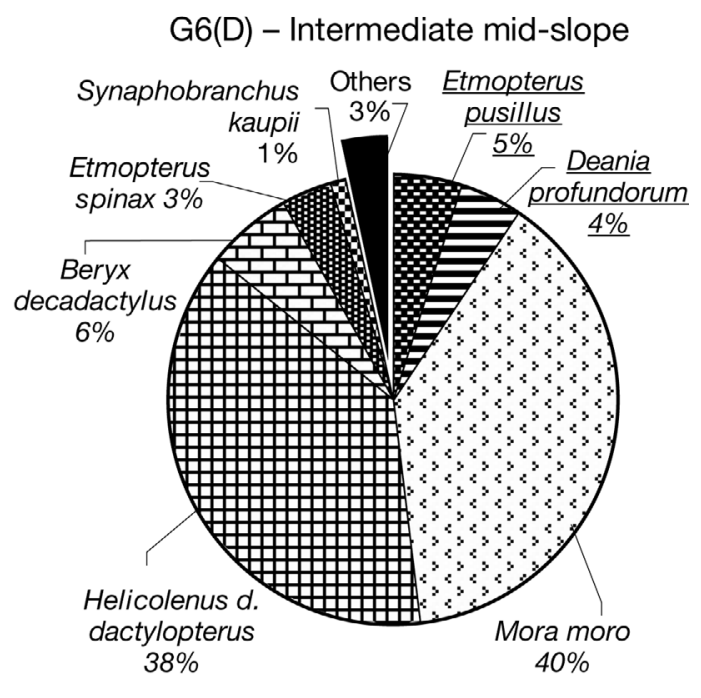

Fig. 12. Relative abundance of indicator species (underlined) and some other common species (not underlined) within each assemblage (Groups G5 to G7)

Assemblage G6 includes the smallest number of species and sample sites (Fig. 12, Table 1). Samples were distributed at an average depth of $755 \mathrm{~m}$, and the significant typifying species are Etmopterus pusilus and Deania profundorum (Table 2). Despite some depthrelated differences from the previous (G5) and following (G7) assemblages, G6 seems impoverished in both the number of species and their abundance, and it can also be characterized by the absence of species from the shelf and shelf-break depth zones.

Assemblage G7 includes the deepest sites sampled, from both island and seamount areas, with an average depth of $963 \mathrm{~m}$. The 158 samples are the most homogeneous in terms of species composition, with 7 species exclusive to this group out of a total of 26 fish species caught (Fig. 12). The significant typifying species of this assemblage are Synaphobranchus kaupii, 
Deania cf. calcea and Mora moro (Table 2). Other common species of this group include Centroscymnus crepidater, Etmopterus pusilus and Aphanopus carbo (Fig. 12).

\section{DISCUSSION}

\section{Species composition}

The 104 species caught from 49 families represent about $22 \%$ of the 460 fish species referenced for the area (Santos et al. 1997). In addition, 8 species were recorded for the first time for Azorean waters: Deania profundorum, Galeus murinus, Centroscymnus crepidater, Centroscymnus cryptachanthus, Somniosus rostratus, Gnathophis mystax, Lepidion eques and Benthodesmus elongatus simonyi. The taxonomic status of Scorpaena azorica and the possible misidentification between specimens of Deania cf. calcea and Deania hystricosa needs to be clarified. The surveyed ichthyofauna was dominated by predators or scavenging benthopelagic and benthic fishes due to the selectivity of the longlines. Several regionally abundant species, such as Sparissoma cretense, Sarpa salpa or orange roughy (Hoplostethus atlanticus), are rarely caught with longlines, while others may also be underestimated due to the gear-related fish losses. Some deep-water species have sharp teeth that easily cut the branch-lines to the hooks (e.g. Aphanopus carbo, several deep-water sharks). Mora moro likely was lost more often because of its soft mouth and the pressure on the hook due to swimbladder swelling during gear retrieval. Understanding community features such as diversity, species composition and species size structure depends on the sampling methods used, and this is a recurring theme discussed in many demersal ichthyofaunal studies (Merrett et al. 1991, Bjordal \& Løkkeborg 1996).

Half of the species caught are subtropical in origin, mainly from the Eastern Atlantic/Mediterranean region, while the other half includes widespread species with global (wide), amphiAtlantic and circumglobal distributions. Despite the dominant eastward ocean currents reaching the Azores, the marine littoral fauna in general have more affinities with the Macaronesian islands and the eastern coasts of the Atlantic (Santos et al. 1995). The higher proximity of the Azores to the eastern continental margin, the past surface currents and glacial events (Briggs 1974, Crowley 1981), and the present oceanographic conditions are determinant factors for the observed biogeographic affinity of the region. The changes of biogeographic affinities with depth (Fig. 4) may reflect a submergence phenomena (i.e. temperate, northern species tend to occupy deeper and colder waters in the southern areas), along with the predominance of northern deep water masses in the region, and the presence of the MAR, which may be an important depth pathway for latitudinal dispersal in the middle of the Atlantic. The increase in the number of species with broad distributions (wide) with depth appears to agree with the expected trend of deeper species occupying significantly larger areas, due to the relative homogeneity and stability of ecological conditions in deeper environments (Merrett \& Headrich 1997).

It is known that the distribution limits, and the dispersal paths of the species, are largely determined by the physical conditions of the ocean. The observed overlap and heterogeneity of the origin of the existing fish fauna may be related to an environmental 'boundary effect' or environmental transition in the North Atlantic. The northern part of the submarine ridge (MAR) extending from Iceland to the Azores is a region in which the environment changes considerably from north to south. The Azores is influenced by the AzC flowing southeastward at about $35^{\circ} \mathrm{N}$, the associated Azores subtropical frontal zone ( 34 to $35^{\circ} \mathrm{N}$ ), the North Azores Flow (NAzF) (39 to $42^{\circ} \mathrm{N}$ ) and the southern branch of the North Atlantic Current $\left(45\right.$ to $\left.48^{\circ} \mathrm{N}\right)$. All these flows have a tendency to converge, enhancing the meridional temperature gradients in the region (Bashmachnikov 2004).

Merrett (1987) proposed a zone of faunal change in the assemblages of the abyssal fish at around $40^{\circ} \mathrm{N}$, reflected in the species richness and dominance. Further sampling confirmed a northerly abyssal fish assemblage at latitudes of 41 to $49^{\circ} \mathrm{N}$ and another group at 31 to $38^{\circ} \mathrm{N}$ (Merrett \& Headrich 1997). Other biotic transitions in the North Atlantic have been described on several occasions and for other taxa at around $40^{\circ} \mathrm{N}$ (e.g. pelagic - Backus 1986). Gomes et al. (2001) identified a demersal fish boundary for the Portuguese continental shelf and slope around $40^{\circ} \mathrm{N}$. Pierrot-Bults (1997) proposed a transition in the abundance and biomass of the macrozooplankton (chaetognaths) at about $40^{\circ} \mathrm{N}$. Angel (1997) and Angel \& Hergreaves (1992) verified a pelagic faunistic transition zone in some planktonic groups, such as the Ostracoda, at about the same latitude. They argued that this corresponds to an area where there is a marked change in the depth of winter mixing, which will affect the seasonality of production in the water column, as well as the fish composition and other aspects of species biology and ecology (e.g. growth, reproduction). The apparent latitudinal ecotone at the Azores, reflected across several taxa, may explain the mixing of the fish fauna, and so the perception that the Azorean ichthyofauna is characterized by many fish species with broad distributions and from various origins (Lloris et al. 1991). 


\section{Fish abundance and distribution}

Dominant species vary with depth, and few species dominated the catch. About $32 \%$ of the species caught were classified as frequent with moderate abundances, and only 3 species were classified as dominant in the habitat where they occurred (Mora moro, Pagellus bogaraveo and Helicolenus d. dactylopterus). In the 5 surveys analyzed, $P$. bogaraveo and $H$. d. dactylopterus account for almost $50 \%$ of the catches among the teleosts. Among the elasmobranch species, Etmopterus spinax, Raja clavata and Galeorhinus galeus account for about $78 \%$ of the total catch. Depth diversity and abundance trends follow the general pattern in which diversity is high at shallower depths and abundance is more evenly distributed when compared with deeper waters.

The climatic tolerance of marine organisms appears more reflected in their depth range than in their latitudinal range (Stevens 1992). In this study, most shelf species had narrow depth distributions (stenobathial), whereas species from intermediate depths (below 200 $\mathrm{m}$ depth) had wider depth distributions (eurybathial) and wider horizontal distributions and generally were more abundant. In this study we found that some ubiquitous shelf species (e.g. Pagellus acarne, Diplodus sargus cadenati and Pagrus pagrus) did not occur at offshore shallower seamounts such as the Princesa Alice Bank (PAL). In the case of Pagellus bogaraveo, the adults and pre-adults occur in seamount and island areas, while the juveniles are only found in island coastal areas. The restricted distribution of these seabream species (Sparidae) to the island coasts seems related to ontogenic changes in diet and special habitat requirements for early life stages (e.g. sheltered habitats). Important differences in ocean and trophic dynamics between seamounts and the island coastal areas largely determine these distribution patterns.

Afonso (2001) reported differences in fish assemblages between the inner-shelf habitats of the Azores islands. The $600 \mathrm{~km}$ length of the archipelago helps explain the higher abundance of subtropical shelf species in the southeastern islands (Sao Miguel and Santa Maria) and the slightly larger number of temperate shelf species in the western and northernmost islands of Flores and Corvo. In this study, Phycis blennoides and Etmopetrus spinax were frequent in the central and eastern islands and absent in the western islands. The separation of the central and eastern islands from the western islands by the MAR may be responsible for this pattern. The Iceland-Faroe Ridge affected the exchange of deepwater species between the North Atlantic Basin and the Norwegian Sea (Bergstad et al. 1999). The Walvis Ridge (southeastern Atlantic) affected the northward spread of Antarctic bottom water, thereby changing the hydrography and ecology (Angel 1997).

\section{Spatial ecological structure}

The spatial structure of assemblages can be determined by trophic interactions between species and by the way in which individuals respond to a range of environmental variables (Rogers et al. 1998). Quasidiscrete boundaries between species assemblages usually are associated with sharp changes in the physical environmental, and conversely, gradual changes in species associations reflect gradual changes in the environmental conditions (Bianchi 1992a). The spatial patterns along depth gradients can occur as zonation or simply the continuous replacement of species with depth (Merrett \& Haedrich 1997). Vertical zonation of ichthyofauna is well documented from shelf to abyssal depths. In the shelf and slope assemblages, depth and bottom type usually are considered the main structuring factors of the demersal ichthyofauna (Bianchi 1992a,b,c, Demestre et al. 2000, Gomes et al. 2001, Williams et al. 2001). Because some factors influencing species ecology (e.g. primary production, temperature, light intensity, density, oxygen and nutrient concentrations) are strongly influenced by depth, it is difficult to specify which of the environmental factors primarily is responsible for the spatial biotic changes observed (Bianchi 1992a, Gaertner 2000).

In this study, the bathymetric distributions of the species ('ichthyocline', Fig. 7) and the general patterns of abundance and biomass indices with depth suggest the existence of 3 main depth-related faunistic discontinuities. Depth zonation was most distinct between the coastal/island shelf/shelf break ( 0 to $200 \mathrm{~m}$ ) and the upper slope (200 to $600 \mathrm{~m}$ ), the upper-slope and midslope (600 to 800/900 m), and between mid-slope and deep mid-slope (below 800/900 m). This bathymetric profile of the coastal and slope-dweller fishes seems coincident with the known local vertical hydrographical gradients. The shallowest assemblage, distributed mostly at less than 150 to $200 \mathrm{~m}$ depth, appears roughly circumscribed by the euphotic shelf-break zone, while the intermediate assemblage (shelf-break/ upper-slope) coincides with the core distribution of the North Atlantic Central Water (NACW). The deep assemblages at mid and deep mid-slope depths might be delimited by the Mediterranean Water (MW) that penetrates into the region at about the 800 to $1000 \mathrm{~m}$ depth and by the upper limits of influence of intermediate waters (SAIW, LSW and AAIW). The upper limit of the deeper fish assemblage also coincides with the lower limit of the oxygen local minimum zone and permanent thermocline. The presence of a zone of relatively low oxygen content may explain the minimum values of the abundance and biomass indices in the 650 to $850 \mathrm{~m}$ depth interval, which has been also observed elsewhere (e.g. Rogers 2000, Levin 2002). 
Williams et al. (2001) among others (e.g. Fock et al. 2004 in the Atlantic) also found a similar link between the local hydrographic features and the community structure of the demersal fish fauna of the continental slope of Western Australia. The conservative properties of slope water masses (e.g. temperature, salinity) along with the prevailing depth-related physical properties (e.g. the thermocline location, $\mathrm{O}_{2}$ concentration, density) provide the required scenario for the evolution of spatially consistent and persistent-depth ecological patterns, both demersal and pelagic. The environmental structuring factors (e.g. water masses) must be established over evolutionary times if they are to form consistent factors in assemblage structure or faunal depth zonation. The main vertical pattern found in this work also agrees with the well-known vertical delineation of pelagic assemblages: the epipelagic, mesopelagic (shallow and deep) and bathypelagic zonation. Given that most of the species caught are benthopelagic feeders (Fig. 5), the vertical depth profile of the potential prey groups (pelagic nekton) can be thought of as a structuring factor, and their distribution should in part be reflected in the depth profiles of demersal ichthyofauna.

The BIO-ENV analysis confirms a high correlation of main sample clusters with depth and temperature. It also shows a decreasing trend in the strength of the correlations between the abiotic/biotic assemblage structures from the shallower to deeper groups. This may indicate that the deeper fish assemblages are marginally affected by the set of variables analysed, and/or an increase in the homogeneity of the biotic and abiotic components with depth.

Clear and sharp segregation of shelf assemblages as observed in this work is well documented as a general pattern, and has been observed, for example, for other Atlantic locations, including the western African shores of Angola, Congo and Gabon (Bianchi 1992b,c), in the middle Atlantic Bight (Colvocoresses \& Musick 1984), on the Grand Bank (Gomes et al. 1992), on the Scotia Shelf (Northwest Atlantic; Mahon \& Smith 1989), on the mainland Portuguese coast (Gomes et al. 2001) and in the Madeira and Cape Verde archipelagos (Menezes 2003). In shallower waters, environmental transitions (e.g. water physical gradients and habitat heterogeneity) generally are more extreme and occur at finer time and spatial scales, which is reflected in the higher observed species diversity and in the small-scale assemblages found in this study.

Four small-scale assemblages were delineated for shallower waters. The inner-shelf-island, hard-bottom assemblage (G1) resembles the 'deep guild' identified by Afonso (2001) for the shore fish communities of the Azores. It is characterized by high diversity, and the most typical species observed are found preferentially in the island hard/rocky bottoms (Serranus atricauda, Diplodus sargus, Pagrus pagrus and Physis physis). The second assemblage (G2 - outer-shelf-island, softbottom assemblage), is mainly composed of island shore samples but with species typical of sandy or sandy/rocky mixed substrates (e.g. Pagellus acarne, Raja clavata and Galeorhinus galeus). Both assemblages resemble the 'shallow southern' group identified by Gomes et al. (2001) for the Portuguese continental shelf, characterized by the presence of several sparid species (seabreams).

Two assemblages (G3 and G4) corresponded to transitional zones composed of a mix of species from the shelf and upper slope zones. The distinctness of the seamount/island-shelf/shelf-break assemblage (G3) may be linked to known differences in ocean dynamics and trophic patterns of seamount areas (Rogers 1994, Koslow 1997). The ecological patterns observed in Assemblage G3 is characterized by high concentrations of adults of Trachurus picturatus (and Scomber japonicus), which constitutes a ubiquitous association observed in the summits of shallow seamounts that penetrates the euphotic zone (e.g. Princesa Alice Bank or D. João de Castro Bank). In areas of seasonal upwelling on the Portuguese shelf, Gomes et al. (2001) found that species lower within the trophic web are mainly found closer to shore, whereas species dependent on secondary or tertiary production, such as adults of horse mackerel (Trachurus trachurus), extend their distribution further offshore. For some species, the island shelf areas seem to function as nursery or growth zones, while the seamount/bank offshore areas are preferentially a feeding zone where adult fishes predominate. This pattern was observed for Pagellus bogaraveo and T. picturatus, which have different size structures between island and bank areas (Menezes et al. 2001). Assemblage G4 (transitional shelf/break) seems characteristic of high steepness sites, which results in smaller values of diversity and abundance and in a higher proportion of benthopelagic species (e.g. Lepidopus caudatus, T. trachurus and P. bogaraveo) and lower abundance of benthic species from less rough bottoms (e.g. Helicolenus d. dactylopterus).

The upper-slope assemblage (G5), is characterized by the near absence of shelf species. The relatively high abundance and biomass indices for this cluster might be related to the distribution of mesopelagic organisms. There is a continuous scattering layer at about 400 to $600 \mathrm{~m}$ depth in the region (Hareide \& Garnes 2001, Fock et al. 2004) along the MAR. This layer is composed of large densities of micronekton, planktonic organisms and various species of mesopelagic fishes. Most of the benthopelagic fishes of this assemblage prey on this mesopelagic nekton (e.g. Beryx splendens feed on this scattering layer; Mauchline \& 
Gordon 1985, Morato et al. 1998, Hareide \& Garnes 2001). Enhanced demersal fish production at the mesopelagic depths likely supports the demersal fishery, which mainly targets the species of these intermediate depths.

The intermediate mid-slope assemblage (G6) coincides with MW intrusions in the region and an oxygen minimum (Johnson \& Stevens 2000). This environmental transition seems reflected in the sharp discontinuity of decreased abundance at 800 to $900 \mathrm{~m}$ depth and lower diversity compared to the adjacent upper and lower assemblages. The MW (higher salinity and low oxygen content) also appears to affect the characteristic faunal elements south of the Rockall Trough, as suggested by Gordon et al. (1996); however, in our study no special or exclusive fish species were found in this assemblage, as was found south of the Rockall Trough.

The deep mid-slope assemblage (G7) appears with the transition between the deep-mesopelagic and shallow-bathypelagic fauna. The transition is coincident with the limit of the permanent thermocline, an increased oxygen content and the influence of the subpolar intermediate waters (SAIW and LSW). Zonation and peaks of abundance and diversity have been observed at the upper and lower boundaries of oxygen-minimum zones (Rogers 2000). The slight diversity enrichment observed around $1000 \mathrm{~m}$ depth and the clear increase in abundance indices also give some ecological consistency to this assemblage. This faunistic transition, also observed in the North Atlantic and in the Mediterranean (Stefanescu et al. 1993, Haedrich 1997, Hareide \& Garnes 2001, D'Onghia et al. 2004) and for different taxonomic groups, has been suggested as the delimitation of the deep-sea fauna (Dinter 2001). The increase in benthopelagic fishes at these depths seems related to the abundance of deepmesopelagic micronekton prey (Mauchline \& Gordon 1985), which in turn may be related to the environmental changes observed.

We found that the delineation of the shallower fish assemblages appears more affected by small-scale environmental factors such as the geomorphologic bottom features (e.g. substratum type, steepness) and small-scale/mesoscale oceanographic characteristics of the habitat (e.g. seamount/islands). In contrast, the deeper assemblages seem to be delineated by largerscale oceanographic and hydrographic features (e.g. water-mass boundaries, oxygen content).

The characterization of areas of homogeneous species composition is relevant for both ecological studies and multispecies management. Some of the ecological features and patterns found in this work would benefit from further research, by collecting more detailed information on the oceanographic and bottom features, and further investigation of the trophic ecology to clarify the general patterns and assembly rules. The assemblages and spatial patterns are valuable for inference, prediction and evaluation of potential changes within the fish-community structure. The assemblage concept can be an appropriate operational or conceptual framework for management and modelling application (Overholtz \& Tyler 1985). In the Azores, the demersal fisheries are important for the local economy, even though catches are small $(<5000 \mathrm{t}$ $\mathrm{yr}^{-1}$; Menezes 2003). Most species are caught at the island shelf and on the flanks of the islands and seamounts and are therefore limited by the small size of suitable habitats. The multispecific nature of the fishery, the discrete and geographically dispersed fishing grounds and the complex spatial structure of their populations makes fishing assessment and management in the Azores particularly challenging. Our study provides a valuable basis for a habitat-level ecological approach to local fisheries management.

Acknowledgements. The data used is a result of several years of research work performed at the Department of Oceanography and Fisheries (DOP) of the University of the Azores (UAç). obtained in several cruise surveys under several research projects performed in the period 1995 to 2000, some of them co-financed by the European Commission (Study contracts 94/034 and 95/05 EU DG-XIV), others financed by the Azores Regional Government (1998/2000 - Monitorização Anual das Abundâncias de Espécies Demersais e de Profundidade nos Açores - MAREDA). We are very grateful to many DOP colleagues, former students and research fellows, for the assistance with the field work at sea and in many tasks of the projects we implement during these years, and to all the crew members of the RV 'Arquipélago' for their professionalism and friendship during the many months we worked together at sea. Finally, we appreciate the suggestions and valuable comments of the 3 anonymous referees, which helped improve our manuscript.

\section{LITERATURE CITED}

Afonso P (2001) Padrões espaciais na estrutura da comunidade de peixes costeiros dos Açores. Master Thesis, Universidade de Coimbra

Alves M, Verdière AC (1999) Instability dynamics of subtropical jet and applications to the Azores front systems: eddydriven mean flow. J Phys Oceanogr 29:837-863

Angel MV (1997) Pelagic biodiversity. In: Ormond RFG, Gage JD, Angel MV (eds) Marine biodiversity: patterns and processes. Cambridge University Press, Cambridge, p 35-68

Angel MV, Hergreaves PM (1992) Large-scale patterns in the distribution of planktonic and micronecktonic biomass in the north-east Atlantic. ICES J Mar Sci 49:403-411

Azevedo JM (1997) Estrutura de uma comunidade ictiológica do litoral da Ilha de S. Miguel (Açores): caracterização e variações espaço-temporais. Dissertação para a obtenção do grau de Doutor em Biologia, Universidade dos Açores, Ponta Delgada

Backus RH (1986) Biogeographical boundaries in the open ocean. UNESCO Tech Pap Mar Sci 49:9-13 
Bashmachnikov I, Lafon V \& Martins A (2004) sea surface temperature distribution in the Azores region. Part II: space-time variability and underlying mechanisms. Arquipel Cienc Biol Mar 21A:19-32

Bergstad OA, Bjelland O, Gordon JDM (1999) Fish communities on the slope of the eastern Norwegian sea. Sarsia 84:67-78

Bianchi G (1992a) Demersal assemblages of tropical continental shelves. DrSci thesis, University of Bergen, Bergen

Bianchi G (1992b) Demersal assemblages of the continental shelf and upper slope of Angola. Mar Ecol Prog Ser 81:101-120

Bianchi G (1992c) Study of the demersal assemblages of the continental shelf and upper slope off Congo and Gabon, based on trawls surveys of the RV 'Dr. Fridtjof Nansen'. Mar Ecol Prog Ser 85:9-23

Bjordal A, Løkkeborg S (1996) Longlining. Fishing News Books, Oxford

Briggs JC (1974) Marine zoogeography. McGraw-Hill, New York

Clarke KR, Ainsworth M (1993) A method of linking multivariate community structure to environmental variables. Mar Eco Prog Ser 92:205-219

Clarke KR, Warwick RM (1994) Changes in marine ecosystems: an approach to statistical analysis and interpretation. Plymouth Marine Laboratory, Plymouth

Clifford HT, Stephensen W (1975) An introduction to numerical classification. Academic Press, New York

Colvocoresses JA, Musick JA (1984) Species associations and community composition of middle Atlantic bight continental shelf demersal fishes. Fish Bull 82:295-313

Compagno LJV (1984a) FAO species catalogue. Vol 4, Sharks of the world. An annotated and illustrated catalogue of shark species known to date. Part 1 - Hexanchiformes to Lamniformes. FAO Fish Synop 125[4(1)]:1-249

Compagno LJV (1984b) FAO species catalogue. Vol. 4, Sharks of the world. An annotated and illustrated catalogue of shark species known to date. Part 2 - Carcharhiniformes. FAO Fish Synop 125[4(2)]:251-625

Crowley TJ (1981) Temperature and circulation changes in the eastern North Atlantic during the last 150,000 years: evidence from the planktonic foraminiferal record. Mar Micropaleontol 6(2):97-129

Demestre M, Sáchez P, Abelló P (2000) Demersal fish assemblages and habitat characteristics on the continental shelf and upper slope of the North-western Mediterranean. J Mar Biol Assoc UK 80:981-988

Dias ML, Cascalho A (1991) Experiências de pesca com palangre em águas dos Açores, p 139-156. Relatório da XI Semana das Pescas dos Açores, Horta

Dias ML, Olsen K, Østvedt OJ (1976) Report on a cruise by the R.V. 'G.O. SARS' to the Azores and the coast of Portugal Nov/Dec 1975. ICES CM 1976/J:12

Dinter WP (2001) Biogeography of the OSPAR Maritime Area. A synopsis and synthesis of biogeographical distribution patterns described for the North-East Atlantic. Federal Agency for Nature Conservation, Bundesamt für Naturschutz, Bonn

D'Onghia G, Politou C, Bozzano A, Lloris D, Rotllant G, Sion L, Mastrototaro F (2004) Deep-water fish assemblages in the Mediterranean Sea. Sci Mar 68(Suppl 3):87-99

Dufrene M, Legendre P (1997) Species assemblages and indicator species: the need for a flexible asymmetrical approach. Ecol Monogr 67:345-366

Fock HO, Pusch C, Ehrich S (2004) Structure of deep-sea pelagic fish assemblages in relation to the Mid-Atlantic Ridge $\left(45^{\circ}-50^{\circ}\right)$. Deep-Sea Res I 51:953-978
Froese R, Pauly D (eds) (2005) Fishbase. Available at http:// www.fishbase.org

Gaertner JC (2000) Seasonal organization patterns of demersal assemblages in the Gulf of Lions (north-western Mediterranean Sea). J Mar Biol Assoc UK 80:777-783

Gomes MC, Haedrich RL, Rice J (1992) Biogeography of groundfish assemblages on the Grand Banks. J Northwest Atl Fish Soc 14:13-27

Gomes MC, Haedrich RL, Villagarcía MG (1995) Spatial and temporal changes in the groundfish assemblages on the Northeast Newfoundland/Labrador Shelf, Northwest Atl, 1978-1991. Fish Oceanogr 4:85-101

Gomes MC, Serrão E, Borges M (2001) Spatial patterns of groundfish assemblages on the continental shelf of Portugal. ICES J Mar Sci 58(3):633-647

Gordon JDM, Merrett NR, Bergstad OA, Swan SC (1996) A comparison of the deep-water demersal fish assemblages of the Rockall Trough and Porcupine Seabight, eastern north Atlantic: continental slope to rise. J Fish Biol 49(Suppl A):217-238

Haedrich RL (1997) Distribution and population ecology. In: Randall DJ, Farrel AP (eds) Deep-sea fishes. Academic Press, New York, p 79-106

Haedrich RL, Merrett NR (1988) Summary atlas of deep-living demersal fishes in the North Atlantic Basin. J Nat Hist 22:1325-1362

Hareide NR, Garnes G (2001) The distribution and catch rates of deep-water fish along the Mid-Atlantic Ridge from 43 to $61^{\circ} \mathrm{N}$. Fish Res 51:297-310

Hill MO, Bunce RG, Swan MW (1975) Indicator species analysis, a divisive polythetic method of classification and its application to a survey of native pinewoods in Scotland. J Ecol 63:597-613

Johnson J, Stevens I (2000) A fine resolution model of the eastern North Atlantic between the Azores, the Canary Islands and Gibraltar Strait. Deep-Sea Res I 47: 875-899

Koslow JA (1997) Seamounts and the ecology of deep-sea fisheries. Am Sci 85:168-176

Legendre P, Legendre L (2000) Numerical ecology, 2nd edn. Elsevier Science, Amsterdam

Levin LA (2002) Deep-ocean life where oxygen is scarce. Am Sci 90:436-444

Lloris D, Rucabado J, Figueroa H (1991) Biogeography of the Macaronesian ichthyofauna (The Azores, Madeira, the Canary Islands, Cape Verde and the African enclave). Bol Mus Munic Funchal 43(234):191-241

Mahon R, Smith RW (1989) Demersal fish assemblages on the Scotia Shelf, northwest Atlantic: spatial distribution and persistence. Can J Fish Aquat Sci 46(Supp 1):134-152

Mann KH, Lazier JRN (1996) Dynamics of marine ecosystems. Blackwell Science, London

Mauchline J, Gordon JDM (1985) Trophic diversity in deepsea fish. J Fish Biol 26:527-535

McCune B, Mefford MJ (1999) PcORD 4.25 for Windows: multivariate analysis of ecological data. MjM Software, Gleneden Beach, OR

McKenna JE Jr (1993) Spatial struture and temporal continuity of South Georgian Antarctic fish community. Fish Bull 91(3):475-489

Melo O, Menezes GM (2002) 'Exploratory fishing of the orange roughy (Hoplostethus atlanticus) in some seamounts of the Azores archipelago'. ICES CM 2002/M:26

Menezes GM (2003) Demersal fish assemblages in the Atlantic Archipelagos of the Azores, Madeira, and Cape Verde. PhD thesis, Universidade dos Açores, Horta 
Menezes GM, Rogers A, Krug H, Mendonça A, Stockley BM, Isidro E, Pinho MR, Fernandes A (2001) Seasonal changes in biological and ecological traits of demersal and deepwater fish species in the Azores. Final report, DG XIV/C/1 - study contract 97-081. Universidade dos Açores, University of Southampton, Arquivos do D.O.P. - Série Estudos, $N^{\circ} 1 / 2001$, Horta

Merrett NR (1987) A zone of faunal change in assemblages of abyssal demersal fish in the eastern North Atlantic: a response to seasonality in production? Biol Oceanogr 5: $137-151$

Merrett NR, Haedrich RL (1997) Deep-sea demersal fish and fisheries. The Natural History Museum/Chapman and Hall, London

Merrett NR, Gordon JDM, Stehmann M, Haedrich RL (1991) Deep demersal fish assemblage structure in the Porcupine Seabight (eastern north Atlantic): slope sampling by 3 different trawls compared. J Mar Biol Assoc UK 71:329-358

Morato T, Sola E, Grós MP, Menezes GM, Pinho MR (1998) Trophic relationships and feeding habits of demersal fishes from the Azores: importance to multispecies assessment. ICES CM 1998/O:7

Overholtz WJ, Tyler AV (1985) Long-term responses of the demersal fish assemblages of Georges Bank. Fish Bull 83(4):507-520

Pierrot-Bults AC (1997) Biological diversity in oceanic macrozooplankton: more than counting species. In: Ormond RFG, Gage JD, Angel MV (eds) Marine biodiversity: patterns and processes. Cambridge University Press, Cambridge, p 69-93

Rogers AD (1994) The biology of seamounts. Adv Mar Biol 30:305-350

Rogers AD (2000) The rule of the oxygen minimum in generating biodiversity in deep-sea. Deep-Sea Res II 47:119-148

Editorial responsibility: Otto Kinne (Editor-in-Chief), Oldendorf/Luhe, Germany
Rogers SI, Rijnsdorp AD, Damm U, Vanhee W (1998) Demersal fish populations in coastal waters of the UK and continental NW Europe from beam trawl survey data collected from 1990 to 1995. J Sea Res 39:79-102

Santos RS, Hawkins SJ, Monteiro LR, Alves M, Isidro EJ (1995) Case studies and reviews: marine research, resources and conservation in the Azores. Aquat Conserv Mar Freshw Ecol 5:311-354

Santos RS, Porteiro FM, Barreiros JP (1997) Marine fishes of the Azores: annotated checklist and bibliography. Arquipel Cienc Biol Mar, Suppl 1, University of the Azores, Pouta Delgada

Stefanescu C, Lloris D, Rucabado J (1993) Deep-sea fish assemblages in the Catalan Sea (western Mediterranean) below a depth of $1000 \mathrm{~m}$. Deep-Sea Res 40(4): 695-707

Stevens GC (1992) The elevational gradient in altitudinal range: an extension of Rapoport's latitudinal rule to altitude. Am Nat 140:893-911

Uiblein F, Bordes F, Castillo R (1996) Diversity, abundance, and depth distribution in demersal deep-water fishes off Lanzarote and Fuerteventura, Canary Islands. J Fish Biol 49(Suppl A):75-90

Vinnichenko VI (2002) Russian investigations and fishery on seamounts in the Azores area, p 115-129. Relatório da XVIII e XIX Semana das Pescas dos Açores, Secretaria Regional da Agricultura e Pescas, Horta

Williams A, Koslow JA, Last PR (2001) Diversity, density and community structure of the demersal fish fauna of the continental slope off western Australia (20 to $\left.35^{\circ} \mathrm{S}\right)$. Mar Ecol Prog Ser 212:247-263

Whitehead PJ, Bauchot ML, Hureau JC, Nielsen J, Tortonese E (eds) (1984-1986) Fishes of the North-eastern Atlantic and the Mediterranean, Vols I-III. UNESCO, Paris

Submitted: March 21, 2005; Accepted: February 13, 2006 Proofs received from author(s): September 25, 2006 